\title{
IMOBILIZAÇÃO DA INULINASE DE Kluyveromyces marxianus PARA A HIDRÓLISE DE EXTRATOS DE Helianthus tuberosus L.
}

\author{
Jefferson Willians de Gaspari \\ Engenheiro Agrônomo
}

Orientador: Prof. Dr. FLÁVIO CESAR ALMEIDA TAVARES

\begin{abstract}
Dissertação apresentada à Escola Superior de Agricultura "Luiz de Queiroz", Universidade de São Paulo, para obtenção do título de Mestre em Agronomia, Área de Concentração: Microbiologia Agrícola.
\end{abstract}

P I R A C I C A B A

Estado de São Paulo - Brasil

Dezembro - 1998 
Dados Internacionais de Catalogação na Publicação (CIP)

DIVISĀO DE BIBLIOTECA E DOCUMENTAÇÃO - Campus "Luiz de Queiroz"/USP

Gaspari, Jefferson Willians de

Imobilizaçāo da inulinase de K/uyveromyces marxianus para a hidrólise de extratos

de Helianthus tuberosus L. / Jefferson Willians de Gaspari. - - Piracicaba, 1998.

74 p. : il.

Dissertação (mestrado) - - Escola Superior de Agricultura Luiz de Queiroz, 1998. Bibliografia.

1. Alcachofra jerusalém 2. Enzima imobilizada 3. Frutose 4. Inulina 5. Inulinase 6. Levedura

CDD 660.63 


\section{IMOBILIZAÇÃO DA INULINASE DE Kluyveromyces marxianus PARA A HIDRÓLISE DE EXTRATOS DE Helianthus tuberosus L.}

\section{JEFFERSON WILLIANS DE GASPARI}

Comissão Julgadora:

Prof. Dr. Flavio Cesar Almeida Tavares ESALQ/USP Prof. Dr. Luiz Eduardo Gutierrez ESALQ/USP

Profa. Dra. Marília Oetterer de Andrade ESALQ/USP

Prof. Dr. FLAVIO CESAR ALMEIDA TAVARES Orientador 
"À minha grande companheira" 


\section{AGRADECIMENTOS}

Gostaria de agradecer, principalmente, ao Prof. Dr. Flavio C.A. Tavares, meu orientador e tutor desde os bons tempos do PET;

Agradeço aos professores que me auxiliaram na elaboração desse trabalho, principalmente ao Prof. Dr. Henrique Celso Trevisan, pela ajuda nos trabalhos de imobilização e fornecimento de sillica e ao Prof. Afrânio Garcia, pelo fornecimento de quitina;

Agradeço meus pais pelos esforços dispensados em minha educação, sem os quais não estaria escrevendo estas linhas agora;

Agradeço a Gráfica e Editora Degaspari, pelo "paitrocínio" na confeç̧ão dos exemplares;

Agradeço a meus colegas de trabalho, que atualmente são meus amigos, Beto, Keila, Ana, Julio, Conti, Juan, Jupará, Max e Holandês;

Agradeço minha esposa Daniela pelo incentivo e companheirismo;

Agradeço ao CNPq pela concessão da bolsa;

Enfim, agradeço a todos que, direta ou indiretamente, me auxiliaram na elaboração deste trabalho. 


\section{SUMÁRIO}

Página

LISTA DE FIGURAS …….................................................... viii

LISTA DE SIGLAS E ABREVIATURAS ………….................... $x$

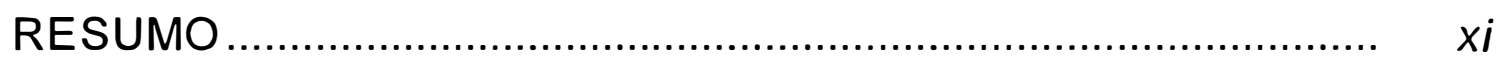

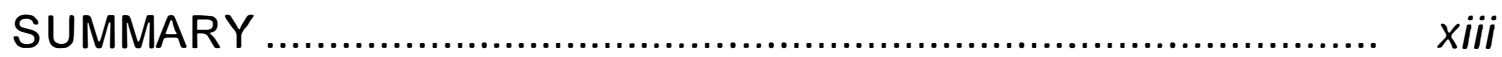

1 INTRODUÇÃO …………………………………………….....

2 REVISÃO DE LITERATURA ………………………................

2.1 Imobilização de Enzimas ......................................................... 13

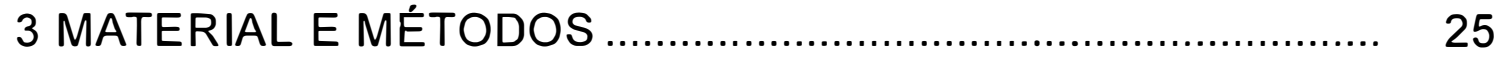

3.1 Extração de Inulina ............................................................... 25

3.2 Obtenção e Extração da Inulinase ......................................... 26

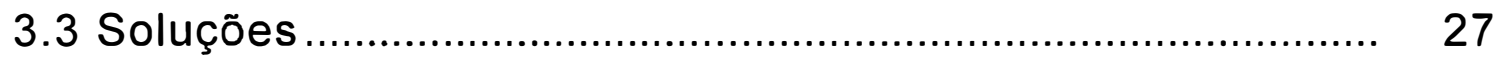

3.3.1 Solução Tampão de Inulina ................................................ 27

3.3.2 Solução Padrão de AR ………………………………..... 27

3.4 Meios de Cultura ................................................................. 28

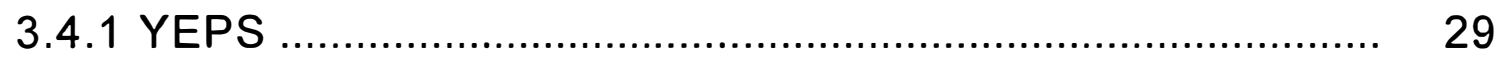

3.4.2 Meio de Extrato de $H$. tuberosus ...................................... 29

3.5 Procedimentos ……………………………………......... 29

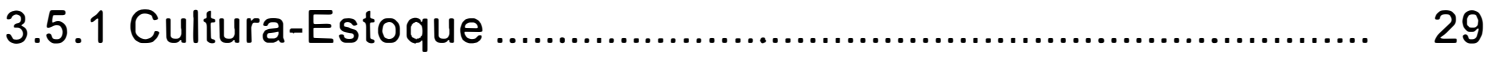

3.5.2 Inoculação da Linhagem ................................................... 31 
3.5.3 Hidrólise Ácida da Inulina ............................................. 31

3.5.4 Análise de Açúcares Redutores ....................................... 32

3.5.5 Análise da Atividade Enzimática ..................................... 32

3.5.6 Análise de Proteínas pelo Método do Biureto .................. 34

3.6 Métodos de Imobilização de Enzimas .................................... 35

3.6.1 Imobilização em Quitina .............................................. 35

3.6.2 Imobilização em Alginato de Sódio ..................................... 37

3.6.3 Imobilização em Pectina .................................................... 38

3.6.4 Contenção da Inulinase em Membrana de Diálise ................ 39

3.6.5 Imobilização em Sílica de Porosidade Controlada (SPC). $\quad 40$

3.6.5.1 Limpeza da SPC ........................................................ 40

3.6.5.2 Silanização da SPC ...................................................... 41

3.6.5.3 Ativação com Glutaraldeido .......................................... 42

3.6.5.4 Imobilização da Inulinase ............................................... 42

4 RESULTADOS E DISCUSSÃO ................................................ 44

4.1 Extração da Inulina .......................................................... 44

4.2 Produção de Inulinase ......................................................... 46

4.3 Características da Inulinase na Forma Livre...................... 47

4.5 Imobilização em Quitina .................................................. 48

4.6 Imobilização em Alginato de Sódio ...................................... 49

4.7 Imobilização em Pectina ........................................................ 50

4.7.1 Determinação da Atividade Pectinolítica no Extrato Enzimático 50

4.8 Contenção da Inulinase em Membrana de Diálise .............. 51

4.9 Imobilização em Sílica de Porosidade Controlada (SPC) ... 53 
5 CONCLUSÕES …................................................................ 5

REFERÊNCIAS BIBLIOGRÁFICAS ....................................... 58

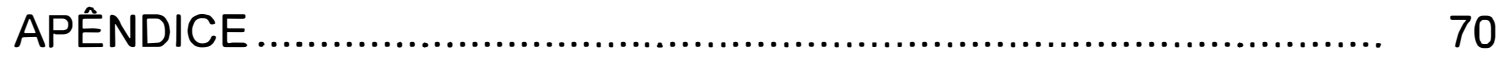




\section{LISTA DE FIGURAS}

Figura 1. Áreas de cultivo de $H$. tuberosus (BOCK, 1998) ........ 9

Figura 2. Inflorescência de $H$. tuberosus ................................ 10

Figura 3. Tubérculos de H. tuberosus ...................................... 10

Figura 4. Esquema das diferentes formas de imobilização de enzimas (TREVAM, 1980)

Figura 5. Esquema de uma molécula de alginato de sódio (GEMEINER et al, 1994)

Figura 6. Esquema do gel formado por alginato de sódio (GEMEINER et al, 1994)

Figura 7. Esquema da semelhança entre o alginato e a pectina (GEMEINER et al, 1994)

Figura 8. Coluna de imobilização em quitina

Figura 9. Contenção da inulinase em membrana de diálise

Figura 10. Esquema de imobilização de enzimas em SPC

Figura 11. Curva característica de atividade em função da temperatura da inulinase em sua forma livre, num substrato $1 \mathrm{~g} / \mathrm{l}$ inulina por $10 \mathrm{~min}$. 
Figura 12. Curva característica de atividade em função do pH na temperatura de $45^{\circ} \mathrm{C}$ da inulinase em sua forma livre, num substrato $1 \mathrm{~g} / \mathrm{l}$ inulina por $10 \mathrm{~min}$.

Figura 13. Tempo de incubação da inulinase imobilizada em alginato, em duas concentrações, pela formação de AR resultante da hidrólise enzimática da inulina

Figura 14. Quantidade de AR recuperado por diálise em função do tempo 52

Figura 15. Avaliação da imobilização da inulinase em SPC em três ensaios consecutivos, em substrato $10 \mathrm{~g} / \mathrm{l}$ inulina a temperatura de $45^{\circ} \mathrm{C}$ e $\mathrm{pH} 7,0$, com $200 \mathrm{mg}$ de suporte

Figura 16. Curva de temperatura da inulinase imobilizada em SPC, em pH 7,0

Figura 17. Curva de $\mathrm{pH}$ da inulinase imobilizada em SPC, a $45^{\circ} \mathrm{C}$... 


\title{
LISTA DE SIGLAS E ABREVIATURAS
}

\author{
$\gamma$-APTS …............ $\gamma$ - amino propil trietoxi silano \\ AR .......................açúcares redutores \\ ART ..................... açúcares redutores totais \\ HFCS .................."high fructose corn syrups"; xarope de milho com \\ alto teor de frutose \\ SPC ......................sílica de porosidade controlada \\ U ...........................unidades da enzima \\ UHFCS ..............."ultra high fructose corn syrups", xarope de milho \\ com teor ultra alto de frutose \\ YEPS .................. meio de cultura com extrato de levedura $(1 \%)$, \\ peptona $(1 \%)$ e sacarose $(2 \%)$
}




\section{RESUMO}

Este trabalho se propôs a estudar a conversão enzimática da inulina de Helianthus tuberosus pela inulinase imobilizada de Kluyveromyces marxianus, como uma via alternativa de produção de xarope de frutose.

A inulina foi extraída dos tubérculos de $H$. tuberosus, desproteinizada e concentrada a $25 \%$ de açúcares redutores totais.

A inulinase foi produzida, concentrada e imobilizada em diversos suportes, como quitina (com e sem glutaraldeído), alginato de sódio (nas concentrações de 2 e $4 \%$ ), pectina, membrana de diálise e sílica de porosidade controlada.

As imobilizações em quitina com e sem glutaraldeído apresentaram taxa de imobilização de, respectivamente, 73 Unidades/g quitina e $48 \mathrm{U} / \mathrm{g}$, entretanto a hidrólise de $1 \mathrm{~g} / \mathrm{l}$ inulina foi muito baixa em ambos os tratamentos, o equivalente a $0,2 \%$ de hidrólise em 5 min de reação

Em gel de alginato de sódio, nas concentrações de 2\% e 4\% converteram-se, respectivamente, $12 \%$ e $26 \%$ de $50 \mathrm{ml}$ substrato com $1 \mathrm{~g} / \mathrm{l}$ de inulina, com $20 \mathrm{~g}$ de suporte cataliticamente ativo em $1 \mathrm{~h}$.

A imobilização em pectina foi impossibilitada devido à presença de pectinase no extrato enzimático. 
A contenção da enzima em membrana de diálise proporcionou a recuperação de $50 \%$ do ART em $6 \mathrm{~h}$ de funcionamento do sistema. A sílica de porosidade controlada apresentou taxa de imobilização de $43 \mathrm{U} / \mathrm{g}$ de sílica, proporcionando a hidrólise de $51 \%$ de substrato $10 \mathrm{~g} / \mathrm{l}$ de inulina em $90 \mathrm{~min}$, entretanto sua atividade foi se exaurindo rapidamente conforme o andamento do processo. 


\section{SUMMARY}

This work had the purpose to study the enzymatic conversion of inulin from Helianthus tuberosus by immobilized inulinase of Kluyveromyces marxianus, as an alternative way of production of fructose syrup.

Inulin was extracted from $H$. tuberosus tubers, desproteinized and concentrated at $25 \%$ of total reducing sugars.

Inulinase was produced, concentrated and immobilized in quitin (with and without glutaraldeid), sodium alginate (concentrations of 2 and $4 \%$ ), pectin, dialysis membrane and controlled porosity silicate.

In quitin with and without glutaraldeid the imobilization rate was, respectively, $73 \mathrm{Unitys} / \mathrm{g}$ quitin and $48 \mathrm{U} / \mathrm{g}$, however the hidrolisys of $1 \mathrm{~g} / \mathrm{l}$ inulin was very low in both treatments, equivalent to $0,2 \%$ hidrolisys in 5 min of reaction.

In sodium alginate gel, in concentrations of $2 \%$ and $4 \%$ the conversion was, respectively, $12 \%$ and $26 \%$ of $50 \mathrm{ml}$ substrate with $1 \mathrm{~g} / \mathrm{l}$ of inulina, with $20 \mathrm{~g}$ of active support per hour.

It was not possible the immobilization in pectin due to pectinase activity in the enzyme extract. 
The contention of enzyme in dialysis membrane provided the recovery of $50 \%$ of $A R T$ in 6 h of operation of the system.

The controlled porosity silicate presented immobilization rate of $43 \mathrm{U} / \mathrm{g}$ of silica, providing the hidrolisys of $51 \%$ of substrate $10 \mathrm{~g} / \mathrm{l}$ of inulin in $90 \mathrm{~min}$, however the activity exhausted quickly during the course of process. 


\section{INTRODUÇÃO}

O consumo de xaropes de frutose é crescente, principalmente nas indústrias de bebidas refrigerantes. Em 1983 a Pepsi Co Inc. substituia $50 \%$ da sacarose de seus produtos por xarope de miIho de alta densidade em frutose (HFCS), segundo TEAGUE e ARNOLD, 1993. Desde novembro de 1984, o HFCS passou a ser o único adoçante nos refrigerantes Coca-cola e Pepsi-cola nos Estados Unidos (MILCENT, 1989).

A presente pesquisa é uma continuidade dos estudos da bioconversão de extratos de Helianthus tuberosus desenvolvidos no Laboratório de Genética de Leveduras da ESALQ/USP, há mais de 15 anos. As pesquisas conduzidas tratam da seleção de leveduras capazes de hidrolizar a inulina; da base genética dos caracteres associados; da produção de álcool; da obtenção de xarope de alta densidade em frutose; da ração animal; da identificação e caracterização das enzimas envolvidas no processo; da determinação dos fatores genéticos e ambientais que influenciam a fermentação e do meIhoramento para o aumento da atividade inulinolítica (GASPARI, 1995; PEREIRA, 1989; LAGUNA, 1986; LAGUNA et al, 1985). Estes trabaIhos pouco se detiveram no estudo da inulinase imobilizada, fato que 
justifica este trabalho, onde se estuda uma via alternativa de produção de um xarope de alta concentração de frutose, utilizando a inulinase imobilizada de $K$. marxianus na hidrólise da inulina de tubérculos de alcachofra de jerusalém (Helianthus tuberosus L.). O objetivo maior foi centralizado nos aspectos da produção e extração da enzima e utilização de suportes atóxicos para imobilização, não contaminantes do hidrolizado e de fácil obtenção e manuseio. 


\section{REVISÃO DE LITERATURA}

A frutose é um monossacarídeo encontrado em estado natural em diversos alimentos, obtido originalmente de plantas que contêm inulina (polímero de frutose), como a dália, chicória e alcachofra de jerusalém (Helianthus tuberosus). Só posteriormente a esta forma de obtenção suas fontes passaram a ser a sacarose da cana e da beterraba e o amido de milho, batata e arroz.

A frutose apresenta muitas propriedades físicas, químicas e metabólicas que a tornam uma matéria prima bastante versátil para a indústria alimentícia. É o açúcar natural mais doce, soluções de frutose possuem maior pressão osmótica que soluções de sacarose na mesma concentração, são menos viscosas do que as de sacarose e permite estocagem a concentrações mais elevadas, com menor risco de cristalização (SOUZA et al, 1990).

A frutose é um substituto da sacarose em alimentos para diabéticos, pois entra no metabolismo humano sem a liberação inicial de insulina e sua absorção pelo sangue é mais demorada do que a da glicose. A insulina não é necessária no transporte da frutose para os tecidos periféricos do fígado e para sua fosforilação e transformação em glicogênio. $O$ efeito sinérgico da frutose com a sacarina 
é maior do que o da sacarose com a mesma, ampliando ainda mais o seu uso em alimentos dietéticos. Em mistura com a sacarina, pode se tornar sete vezes mais doce que a sacarose, com apenas $1 / 7$ de seu teor calórico, além de ser um excelente mascarador do sabor amargo deixado pela sacarina. Reduz em até $25 \%$ a incidência de cáries quando se substitui a sacarose completamente da alimentação humana (LAGUNA, 1986). Adicionalmente, este monossacarídeo acelera o metabolismo do etanol e aumenta a absorção de ferro através da formação de um complexo quelante ferro-frutose. Quando adicionada à fontes protêicas, reage com os grupamentos amina formando complexos aromáticos agradáveis. Por ser açúcar redutor, reage com aminoácidos (reação de Maillard) gerando compostos de cor amarelo dourado a marrom escuro, de odor e sabor típicos. Assim, quando usada em panificação intensifica a coloração típica destes produtos (MILCENT, 1989).

Tendo-se como objetivo a substituição da sacarose em alimentos e bebidas, introduziu-se no mercado americano em 1967 e 1977, respectivamente, os HFCS-42 ("High Fructose Corn Syrups"), com $42 \%$ de frutose, $52 \%$ de glicose e $6 \%$ de outros açúcares (na fração dos açúcares); e HFCS-55, com 55\% de frutose. Estes xaropes são obtidos a partir do amido de milho, que é hidrolisado a glucose por via ácida ou enzimática ( $\alpha$-amilase e amiloglucosidase) seguida pela isomerização da glicose por tratamentos alcalinos ou, mais comumente, por via enzimática pela glicose isomerase imobilizada 
(BARKER e PETCH, 1985; ANTRIM et al, 1979). A fração açucarada do xarope resultante é constituído por $42 \%$ de frutose, $50 \%$ de glicose e $8 \%$ de outros açúcares. O xarope pode então ser progressivamente enriquecido em frutose, através de colunas cromatográficas, em até $90 \%$, produzindo o chamado UHFCS ("Ultra High Frutose Corn Syrups"). Este último passo, no entanto, onera a produção (HIGLEY \& WHITE, 1991).

A hidrólise de extratos de $H$. tuberosus permite a obtenção de xaropes com média de $75 \%$ de frutose, o que é consideravelmente mais elevado do que aqueles obtidos a partir da isomerização de glicose de amido de milho (KIERSTAN, 1980). A hidrólise química da inulina pode ser conduzida com ácido cloridrico, ou mais comumente, com ácido sulfúrico em temperaturas elevadas. Os tratamentos devem empregar $\mathrm{pH}$ de 1 a 4 e entre 60 e $100^{\circ} \mathrm{C}$ com duração de 5 minutos a várias horas.

$\mathrm{O}$ tratamento de 30 minutos a pH 2 e $110^{\circ} \mathrm{C}$ do extrato de chicória purificado por precipitação calcocarbônica, posteriormente purificado em carvão ativado e resinas de troca iônica, permite a obtenção de xarope com $70^{\circ}$ Brix contendo $97 \%$ de açúcares que correspondem a $75 \%$ de frutose e $25 \%$ de glicose. Porém, a utilização de $\mathrm{pH} 3$ e 4 e temperatura da ordem de 70 a $80^{\circ} \mathrm{C}$ durante hidrólises longas, levam à produção de xaropes com qualidade superior em termos de aroma e cor, impedindo a perda de açúcar por degradação ácida, que ocorre comumente nos tratamentos mais drásticos. Os testes têm mostrado que a condição mais favorável para 
hidrólise é a que emprega $\mathrm{pH} 1,5$ a $85^{\circ} \mathrm{C}$ por 30 minutos a 1 hora, sendo que a elevação do pH além deste ponto leva a tratamentos muito mais demorados, sem melhorar significativamente a qualidade do xarope (FLEMING \& GROOTWASSINK, 1979).

Os xaropes de frutose obtidos através de tratamento ácido devem ser neutralizados, o que normalmente é feito com óxido de cálcio, precipitando-se o cálcio excedente através da formação de carbonato de cálcio com anidrido carbônico. Falhas nesse procedimento, que permitam a presença de pequenas quantidades de cálcio iônico, levam à formação de compostos de sabor amargo, que diminuem a qualidade do produto.

Por causa destas dificuldades, a hidrólise enzimática tem surgido como uma via alternativa que pode vir a possibilitar a aplicação industrial da inulina como uma fonte de frutose.

A inulina é uma glicofrutana presente como carboidrato de reserva em tubérculos de alguns membros da família Compositae, notadamente em Helianthus tuberosus, Dahlia variabilis e em espécies de Inula. Ela foi descoberta em 1804, a partir de extratos de tubérculos de $H$. tuberosus. A inulina é um polissacarídeo linear, formada por residuos $\beta$ - D-frutofuranose unidos por ligações $\beta-2,1$ com uma terminação de $\alpha-D$-glucopiranose idêntica à da sacarose. O número de frutoses encadeiadas é variável, girando em torno de 35 (SHALLENBERG, 1982). 


$$
\beta-D-\text { fruf } 2-[\rightarrow 1 \beta-D-\text { fruf } 2-]_{n} \rightarrow 1 \beta-D-\text { fruf } 2 \rightarrow \alpha-D-G p
$$

A massa molecular da inulina varia entre $3.500-5.500 \mathrm{~g} / \mathrm{mol}$ e é insolúvel em água fria, sendo que a $55^{\circ} \mathrm{C}$ sua solubilidade é de $5 \%$.

A inulina, na nutrição humana, colabora para o aumento da população de bifidobactéria nos intestinos, mas diminui a população de enterococos e enterobactérias (KLEESSEN et al, 1997). É um dos precursores da produção de ácidos graxos de cadeia curta. Sua ingestão na dieta para humanos favorece a flatulência (SOBOTKA et al, 1997).

O Helianthus tuberosus é conhecido sob vários nomes populares, principalmente, Tupinambour nos países latinos e "Jerusalem artichoke" (alcachofra de jerusalém) nos anglo-saxões. Até o momento, se faz o cultivo de $H$. tuberosus para a ração animal, sendo sua utilização muito limitada na alimentação humana.

$\mathrm{OH}$. tuberosus é uma planta com multiplicação vegetativa por tubérculos, podendo também ser obtida a partir de sementes viáveis. Os cruzamentos são facilmente obtidos e o seu cultivo não oferece maiores dificuldades devido à ausência de doenças viróticas.

Os tubérculos apresentam 20 a $26 \%$ de matéria seca, da qual 75 a $82 \%$ são carboidratos solúveis, $13 \%$ celulose e hemicelulose, 6 a $8 \%$ de compostos nitrogenados (proteínas), 1 a $5 \%$ de cinzas e lipídeos em concentrações menores que $1 \%$. Os carboidratos apresentam a fórmula geral G.F. $F_{n}$, sendo considerados 
como inulinas aqueles carboidratos com $n$ maior que 31. Mesmo correspondendo a, no máximo, $15 \%$ dos carboidratos, a inulina pode ser considerada como o carboidrato do $H$. tuberosus, já que os polímeros restantes, de menor tamanho, são da mesma composição e com o mesmo tipo de ligações. Com esta composição, a frutose corresponde a 75 a $98 \%$ dos açúcares redutores totais, sendo o restante glicose (MULLIN et al, 1994).

Essa planta apresenta uma série de vantagens em relação a outras alternativas de cultivares, como a menor exigência agrícola do vegetal, a fácil mecanização do plantio e colheita, a alta produtividade, a ampla distribuição geográfica, a possibilidade de armazenamento dos tubérculos e sua fermentação direta ou com prétratamentos simples e pouco dispendiosos.

A origem do $H$. tuberosus ainda permanece incerta. Este vegetal foi introduzido na Europa procedente dos Estados Unidos e Canadá em 1603, tendo sido usado como alimento pelas tribos indígenas da região. Na América do Sul é incerta a sua introdução, constando o seu cultivo como forragem no Brasil, Argentina e Uruguai desde o século passado, sem excluir a possibilidade de ser um vegetal autóctone desta região. A hipótese mais aceita é que este vegetal é originário das montanhas do norte do México e que foi difundido em tempos remotos para toda a América do Norte. É cultivado na América do Norte, França, Itália, Alemanha, parte ocidental da ex-URSS, China, Índia e África Central, como indica a Figura 1 (BOCK, 1998). 


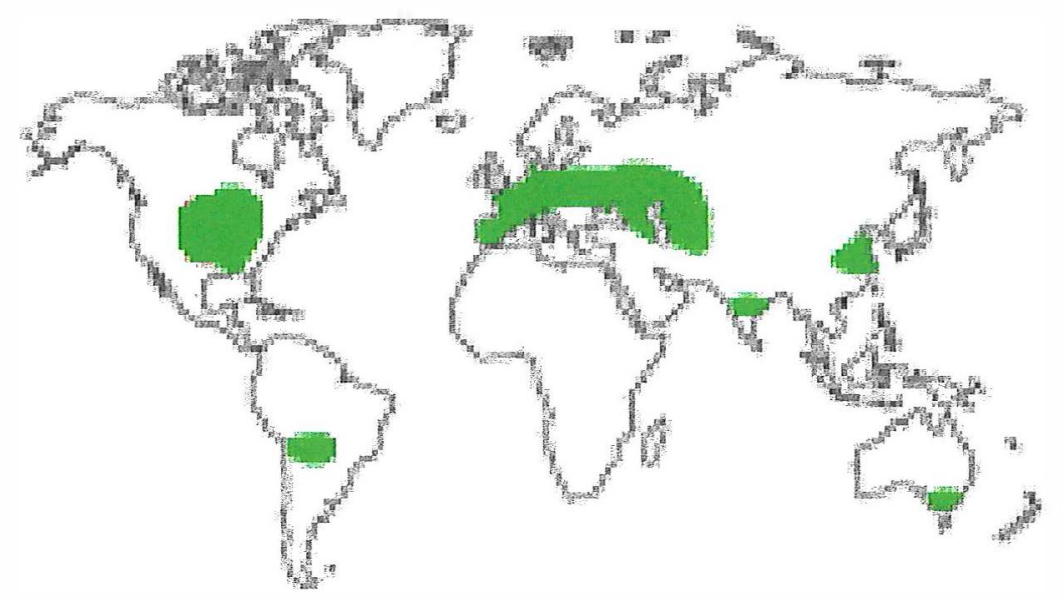

Figura 1. Áreas de cultivo de $H$. tuberosus (BOCK, 1998).

O H. tuberosus é um alohexaplóide complexo $(2 n=102)$ com fórmula (At1 At2 Bt / At1 At2 Bt), sendo Bt um genoma muito semelhante ao Ba do girassol $(H$. annus ; $2 n=34)$. Por causa destas semelhanças e das suas características agronômicas, o H. tuberosus tem sido utilizado em cruzamentos interespecíficos com o girassol (JOSHI et al, 1994; LALYMENKO e LALYMENKO, 1995).

O peso molecular da inulina em $H$. tuberosus varia conforme a estação do ano, interferindo na relação frutose/glicose. As maiores cadeias ocorrem durante o outono e as menores ocorrem durante o verão (GEITEL et al, 1993). A composição permanece constante durante todo o inverno, ocorrendo somente uma pequena variação na composição de açúcares, já que os polifructosídeos são despolimerizados. A estocagem dos tubérculos também causa que- 


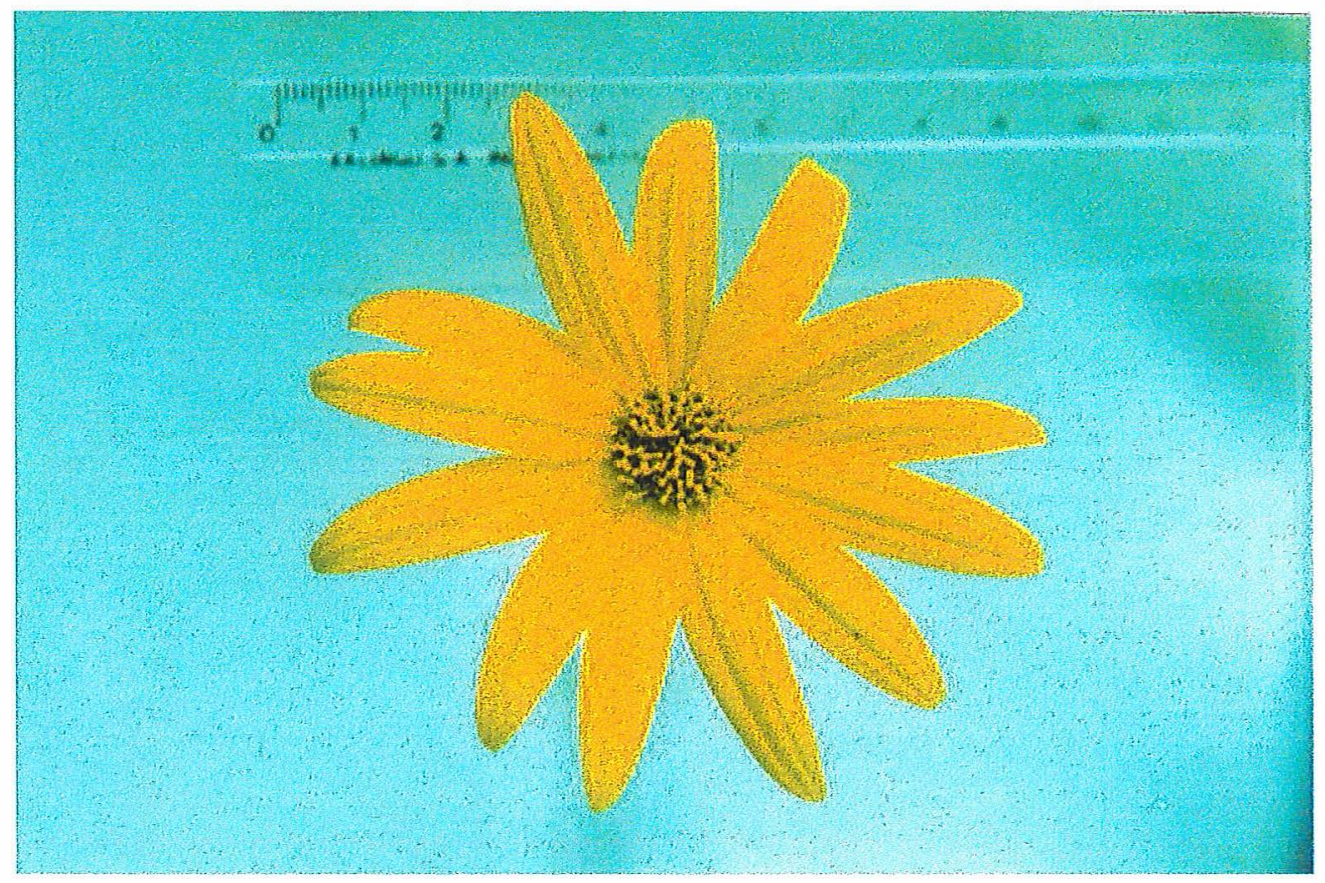

Figura 2. Inflorescência de Helianthus tuberosus

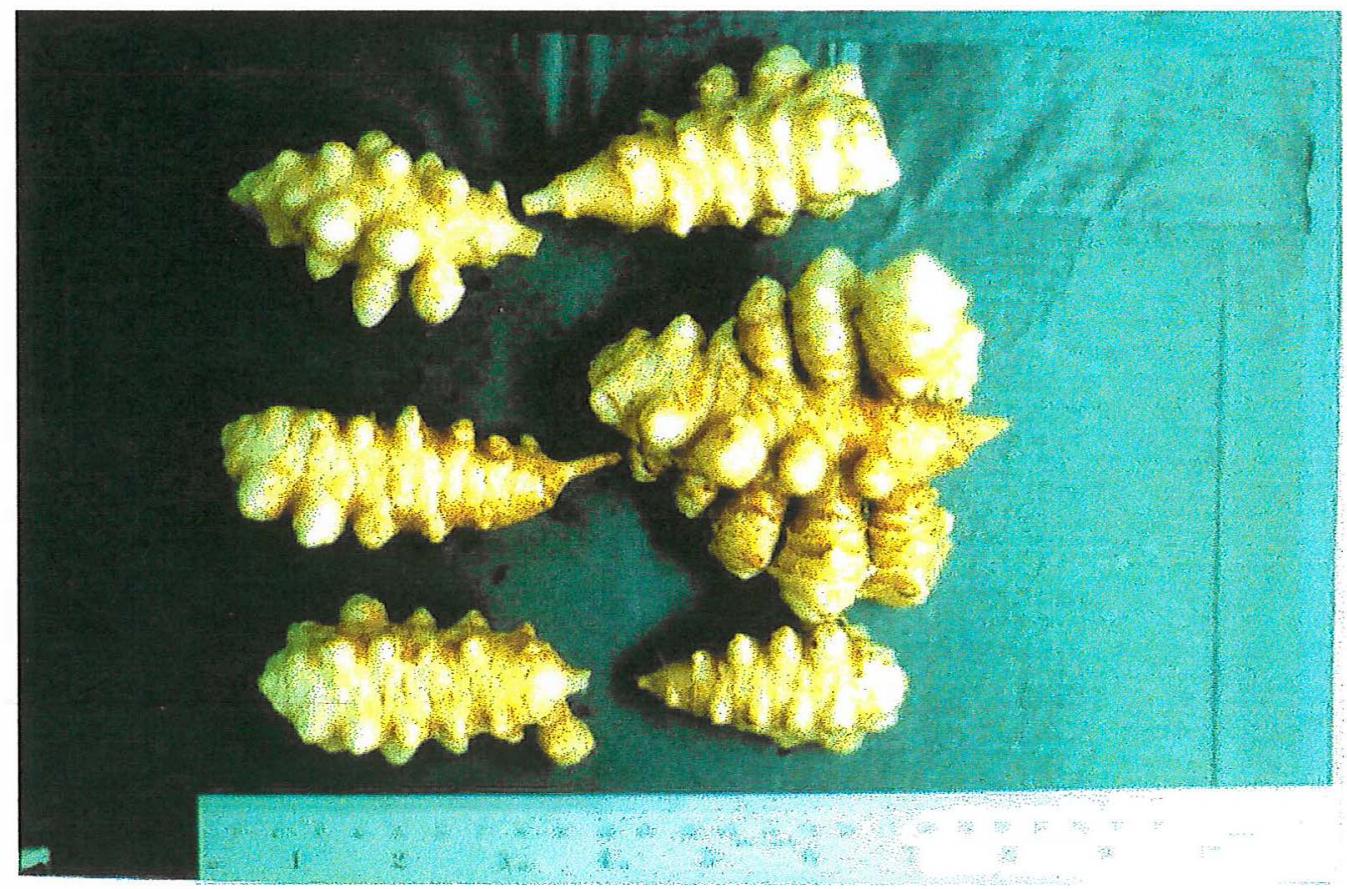

Figura 3. Tubérculos de Helianthus tuberosus 
bra da inulina e oligossacarídios menores. Estas alterações são notadas nas primeiras seis semanas de armazenamento. Com a quebra dos oligossacarídios ocorre um aumento proporcional do conteúdo de sacarose e trissacarídios principalmente, alterando a relação frutose / glicose.

As condições ideais para o cultivo deste vegetal no Brasil vêm sendo estudadas na Universidade do Ceará, com dados promissores para a região Nordeste. Dados experimentais estimam produções de 90 a 120 toneladas por hectare/ano em condições de clima semi-árido, considerando três a quatro ciclos anuais.

Mesmo com as vantagens agrícolas, a utilização de $H$. tuberosus é muito reduzida, predominando o uso como ração animal. A potencialidade industrial deste vegetal vem sendo pesquisada recentemente em vários países com o objetivo principal de produção de etanol, xaropes de frutose e proteína microbiana (PARAMESWARAN, 1994).

A K. marxianus demonstrou ser, dentre muitas outras espécies, a mais promissora para o desenvolvimento de sistemas de hidrólise da inulina de $H$. tuberosus (LAGUNA, 1986), tanto pela sua capacidade de fermentar o extrato de tubérculos desse vegetal, quanto pela sua produção de inulinase.

Por definição, as leveduras do gênero Kluyveromyces apresentam reprodução vegetativa por brotamento; células esferoidais, cilindricas, elipsoidais ou alongadas; podem formar 
pseudomicélios, mas não micélios verdadeiros. Os ascos rompemse quando maduros liberando os esporos, os quais têm tendência a se aglutinar (LODDER, 1970). Os ascosporos podem ter formas variadas predominando os reniformes e esféricos, presentes em número de um a vários dentro do asco. Há interfertilidade; possuem metabolismo oxidativo e fermentativo; requerem vitaminas e formam, em muitos casos, pigmentos vermelhos não carotenóides. Todas as espécies têm grande capacidade fermentativa; não utilizam nitrato como fonte de nitrogênio; a maioria das espécies é resistente a ciclohexamida; ao menos metade das espécies consegue fermentar em meio com mais de $50 \%$ de glicose. O gênero possui 18 espécies, das quais $K$. marxianus, $K$. fragilis e $K$. cicerisporus caracterizam-se por apresentar boa fermentação de inulina.

Dados experimentais demonstraram que a melhor fonte de nitrogênio para a produção da inulinase em $K$. marxianus é a peptona (LAGUNA, 1986; GASPARI, 1995). Dentre outros meios de cultura, o que melhor induziu a produção da enzima foi o YEPS (extrato de levedura, peptona e sacarose). Os meios contendo inulina proporcionam um leve aumento na concentração de inulinase, entretanto encarecem muito a produção.

Uma grande variedade de enzimas foram identificadas com capacidade de hidrolisar as ligações $\beta-2,1$ frutofuranosidase que ocorrem em sacarose e inulina. Essas frutofuranosidases podem ser classificadas em três grupos, de acordo com suas atividades em 
polissacarídeos de diferentes graus de polimerização. No grupo (1), temos as verdadeiras $\beta-2,1$ - frutano - frutano - hidrolases, com alta atividade em inulina e atividade extremamente baixa em sacarose. As enzimas desse grupo ocorrem em tubérculos de $H$. tuberosus, e estão envolvidas com a utilização das reservas da planta. No grupo (2) encontramos as $\beta$ - D - frutanofuranosidio - frutano - hidrolase, com índice de hidrólise em sacarose e inulina em torno de 14.000, neste grupo encontra-se a invertase. O terceiro grupo é representado pelas enzimas com índice de hidrólise sacarose/inulina intermediário, porém muito menor que o da invertase. A ação dessas hidrolases sobre a inulina se dá pela remoção terminal dos resíduos de frutose, até a clivagem da última ligação glicosídica, quando uma molécula de glicose é liberada. Este último grupo de enzimas ocorre em um grande número de microorganismos, tendo sido identificados em vários fungos filamentosos e leveduras.

\subsection{Imobilização de Enzimas}

Imobilização de enzimas pode ser definida como uma retenção da molécula enzimática em uma região que permita troca com o meio, onde se encontra o substrato. O suporte é geralmente insolúvel em água e apresenta um peso molecular muito grande (polímero hidrofóbico).

O aprisionamento da enzima pode se dar de várias maneiras: ligação covalente, adsorção, aprisionamento, entre outras (Figura 4). 
As enzimas podem ser fixadas em uma matriz ou em um gel formado numa solução aquosa, contendo uma ou mais enzimas. A matriz mais comum é a poliacrilamida (KIERSTANG et al, 1985). Esse método é simples e pode ser aplicado para muitas enzimas (SRIVASTAVA et al, 1996; ABDELLAH et al, 1992). As desvantagens desse método são a contínua perda da enzima devido à ampla distribuição de tamanho dos poros no gel; acesso reduzido do substrato à enzima imobilizada; e a perda de atividade enzimática devido à produção de radicais livres durante a reação de polimerização do gel (MARTINEK et al, 1975).

As enzimas podem ser adsorvidas em muitos materiais com superfície carregada, como minerais e resinas trocadoras de íons ou neutros, e suportes poliméricos neutros (GOLDSTEIN et al, 1976). Altas concentrações de sais ou substrato podem promover aumento na taxa de desorção da enzima (ZABORSKY, 1973).

As moléculas de enzima podem ser ligadas covalentemente ao suporte; a fixação pode ser alcançada através de substâncias que liguem a enzima ao suporte, formando uma ponte, ("cross-linkage") como o glutaraldeido (HAYASHI et al, 1993; NIGHOJKAR et al, 1995).

A imobilização de enzimas em quitina é feita, principalmente, através da formação de ligações covalentes entre a enzima e a molécula de quitina, ou por adsorção. A imobilização por adsorção é devida, principalmente, a ligação iônica entre o grupamento amino 

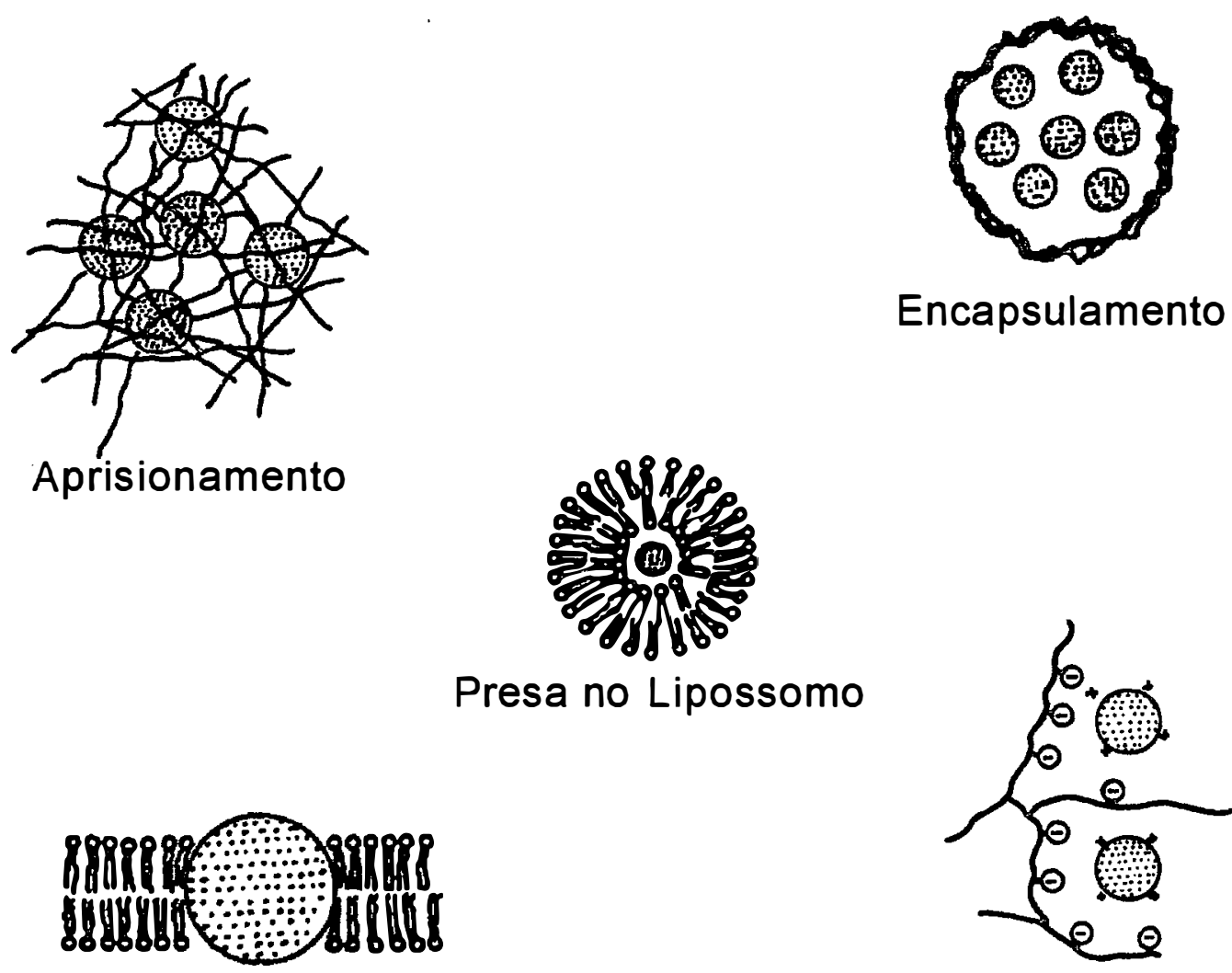

Presa no Lipossomo

Interação Hidrofóbica

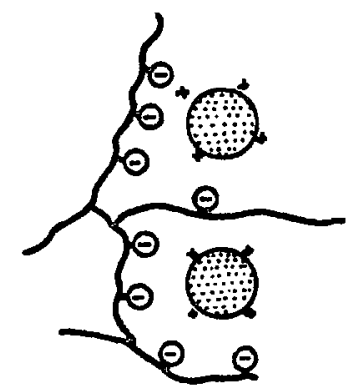

Ligação lônica
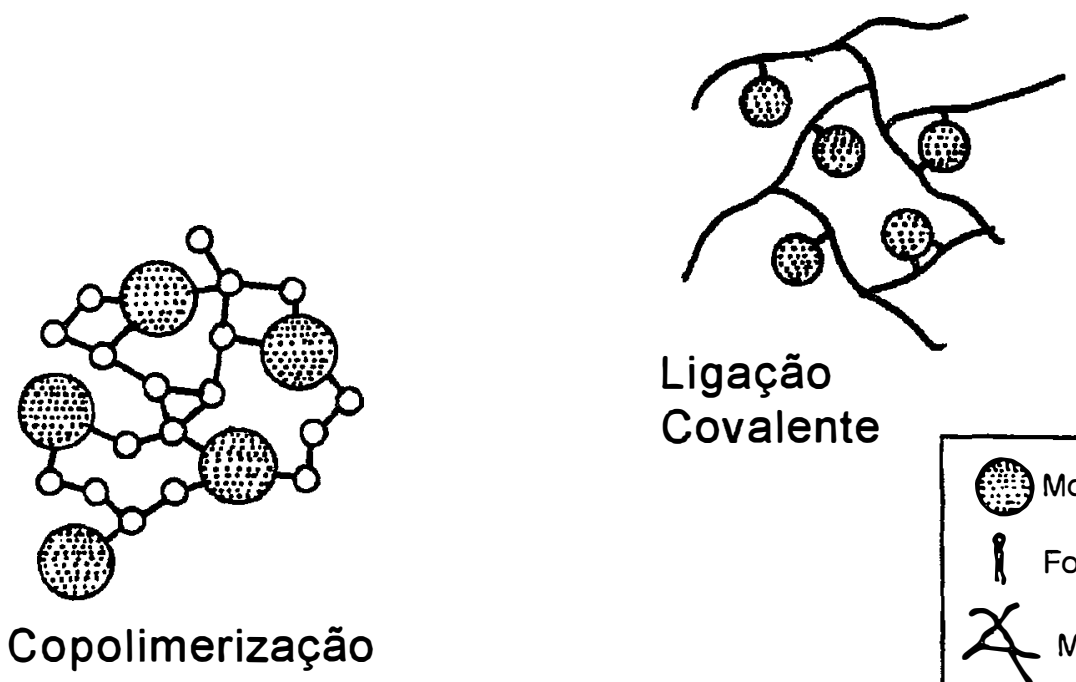

Ligação

Covalente

Figura 4. Esquema das diferentes formas de imobilização de enzimas (TREVAM, 1980). 
da quitina e o grupo carboxílico do ácido glutâmico ou aspártico da enzima; também é devida à pontes de hidrogênio, forças de Van der Waal e interações hidrofóbicas.

A ligação da enzima com a quitina é aumentada com o uso de dialdeídos como o glicosal, malonaldeído e glutaraldeído, os quais reagem com os radicais amino livres da quitina e da enzima, formando ligações covalentes. Ligações cruzadas do glutaraldeído com a enzima imobilizada representam uma perda significativa de atividade.

A imobilização de enzimas em gel de alginato é segura, rápida, simples e barata, podendo ser aplicada em diversos biocatalizadores (PLAHUTA e RASPOR, 1996; PURI et al, 1996; LEE et al, 1993). Resultados satisfatórios têm sido obtidos usando-se baixas concentrações de géis de alginato. O princípio da imobilização em alginato é o aprisionamento físico da molécula enzimática na malha formada na gelatinização do polímero. Esse aprisionamento é impossibilitado em muitas enzimas, principalmente as de tamanho menor, pois as mesmas se escoam pelos largos poros do gel.

Alginatos são sais de ácido algínico e ocorrem como material intracelular de algas marrons. $O$ ácido algínico é composto por 2 tipos de monossacarídeos: ácido manurônico e ácido gulurônico (Figura 5). Esses resíduos estão presentes em proporções variáveis, dependendo da origem do ácido algínico. 

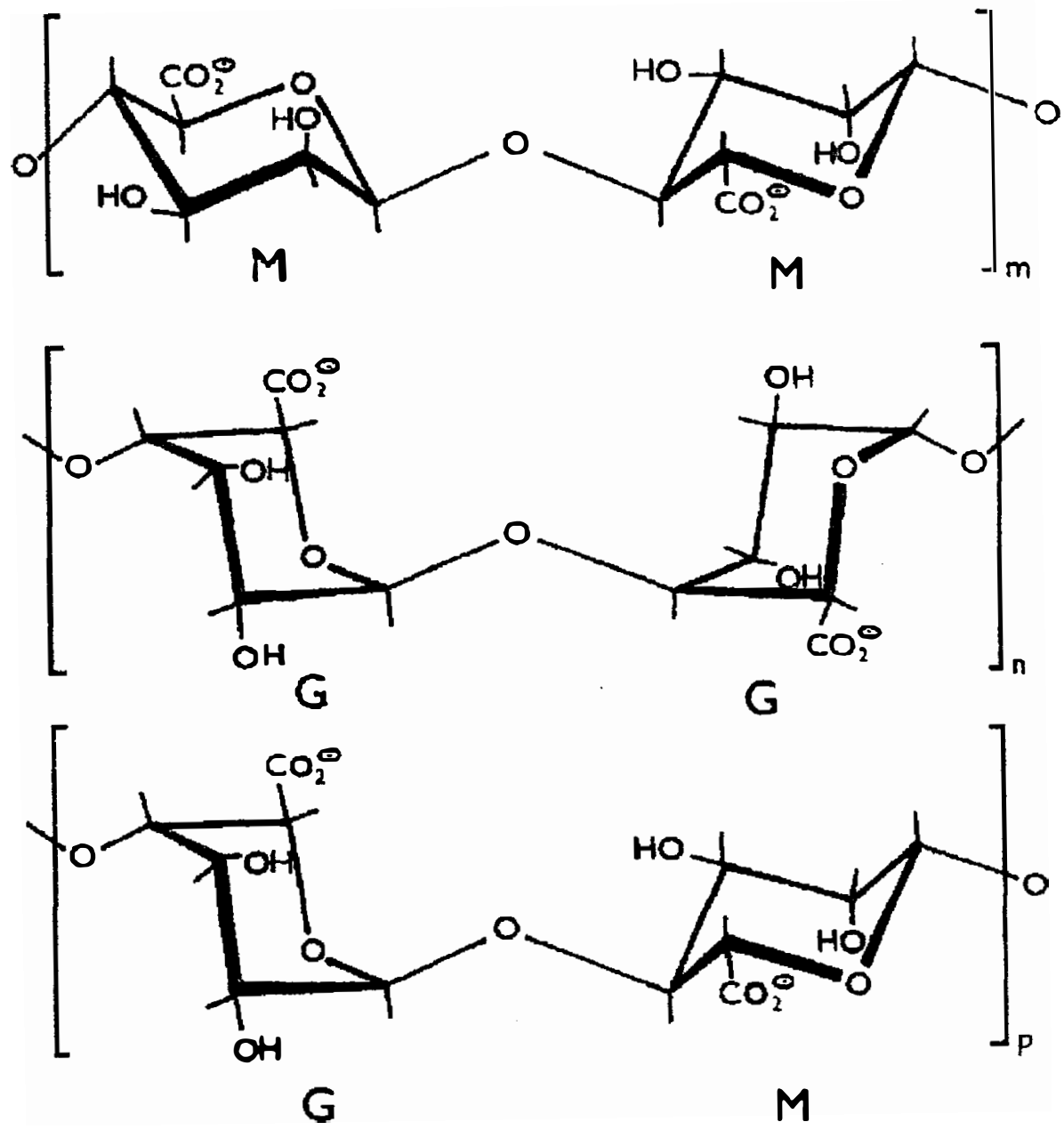

Figura 5. Esquema de uma molécula de alginato de sódio (GEMEINER et al, 1994). 
Os alginatos formam géis em soluções contendo o cátion divalente $\mathrm{Ca}^{+2}$, que não são termoreversíveis (Figura 6).

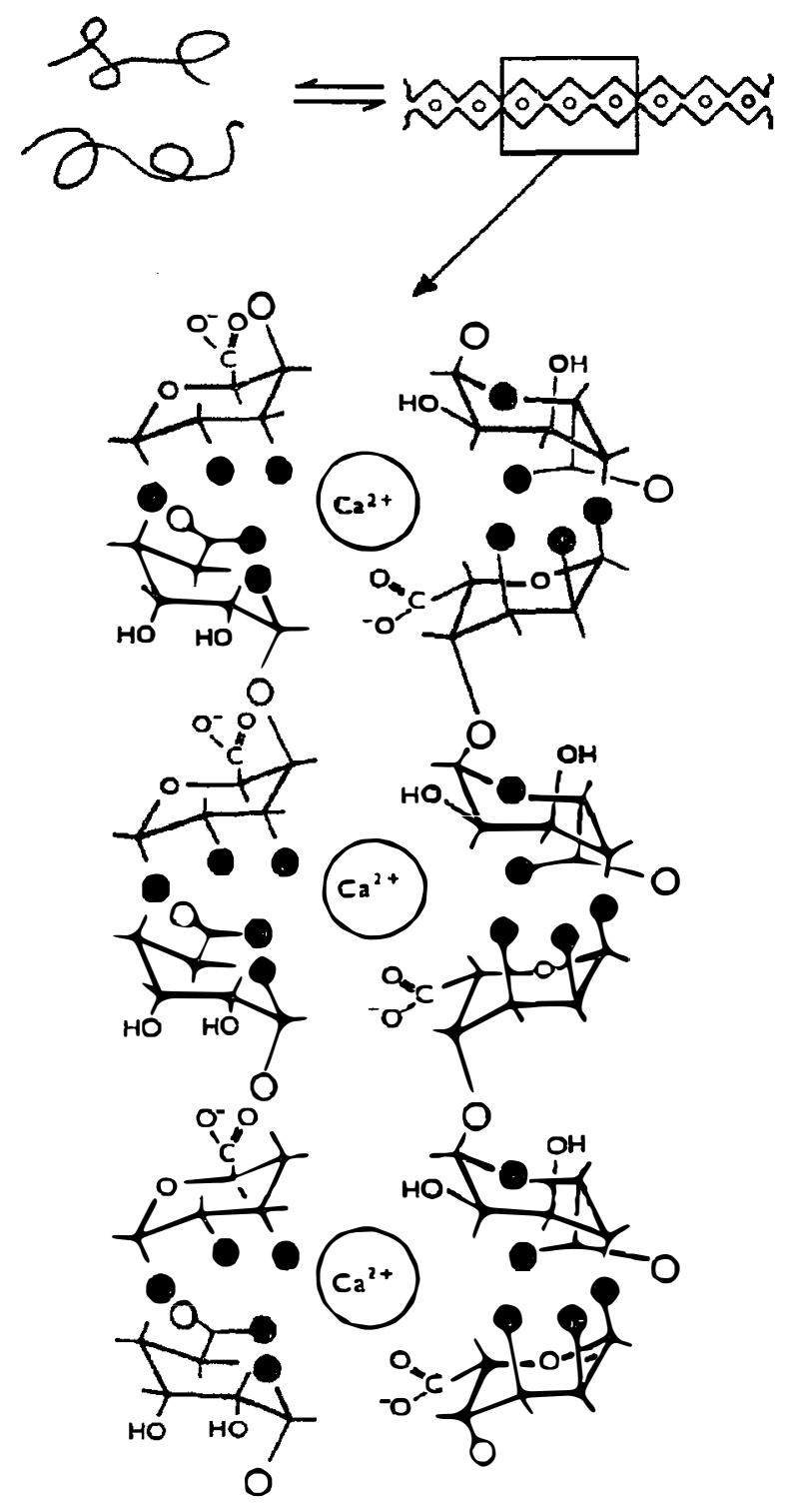

Figura 6. Esquema do gel formado por alginato de sódio (GEMEINER et al, 1994). 
A imobilização em géis de pectina segue os mesmos padrões da imobilização em alginato. Pectinas são polissacarídeos da parede celular com funções estruturais em plantas. São polissacarídeos ramificados em sua forma nativa, entretanto, quando extraídos, apresentam-se predominantemente lineares. A pectina é formada por unidades 1,4 $\alpha-D$ galacturonato e apresenta, em vários aspectos, semelhanças com o alginato de sódio (Figura 7), como por exemplo, a formação de gel na presença de $\mathrm{Ca}^{+2}$.

As moléculas de pectina são compostas por longas cadeias de resíduos de acído galacturônico. Em cada resíduo há um grupo carboxil (- $\mathrm{COOH})$. Às vezes estes grupos são modificados pela adição de um grupo metil $\left(-\mathrm{CH}_{3}\right)$. O resultado é um grupo metoxil $\left(-\mathrm{COOCH}_{3}\right)$. A pectina de laranja é parcialmente metilada.

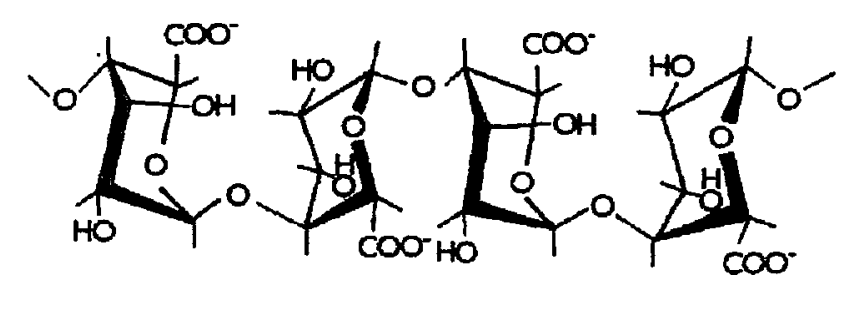

Alginato Poli-L-Guluronato

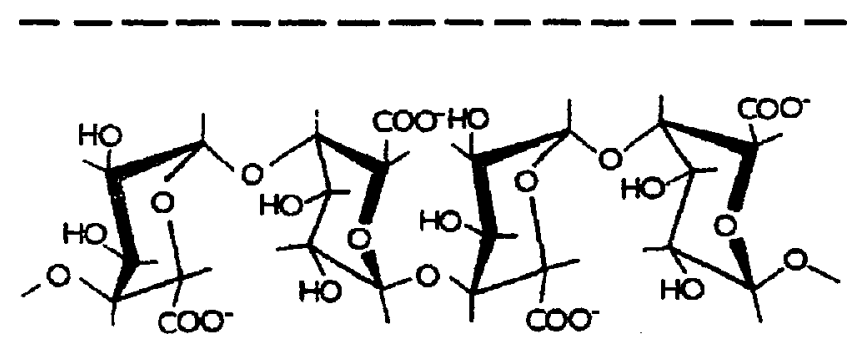

Pectato Poli-Galacturonato

Figura 7. Esquema da semelhança entre o alginato e a pectina (GEMEINER et al, 1994). 
A imobilização da inulinase em sílica de porosidade controlada (SPC) é realizada através de ligação covalente, ocorrendo a formação de uma base de Schiff entre um grupamento aldeídico (previamente ligado à superfície do suporte) e um grupo amino terminal de uma lisina. $O$ reagente $\gamma$-amino-propil trietoxi silano ( $\gamma$-APTS) tem demonstrado muita eficiência em gerar ligações covalentes entre a superfície do suporte inorgânico (geralmente um óxido) a uma enzima. A ponte é gerada através da substituição do resíduo etoxi do silano por um grupo hidroxila.

Antes de se realizar a silanização da SPC, é necessário uma limpeza da superfície da sílica com um agente oxidante (ácido nítrico), seguido por uma dessecação a $115^{\circ} \mathrm{C}$ para ativar o grupo silanol da sílica. É feita então a reação com o $\gamma$-APTS. Uma vez formada a ligação entre a SPC e o grupo aminopropil, a imobilização da enzima já pode ser realizada. Entretanto, a eficiência do método aumenta muito quando o suporte é ativado com algum agente ligante, como o glutaraldeído. Na presença de glutaraldeído em excesso, o grupo amino reage com somente um dos grupos aldeídos do reagente, deixando o outro livre para reagir com a enzima, imobilizando-a (KENT et al, 1978).

Segundo TREVAN, 1980, quando uma enzima é presa num suporte, a atividade enzimática pode ser reduzida por várias razões: a) algumas moléculas podem estar imobilizadas no suporte numa configuração que impeça o acesso do substrato ao sítio ativo; b) o 
sítio ativo pode estar envolvido na ligação com o suporte; proteção do sítio ativo por um inibidor reversível durante a ligação com o suporte pode gerar um aumento da retenção de atividade; c) a molécula enzimática pode se ligar numa configuração que proporcione sua inativação; d) as condições da reação de ligação podem causar denaturação ou inativação da enzima.

A imobilização pode causar mudanças drásticas nos parâmetros característicos da reação enzimática, como por exemplo, a velocidade máxima de reação, a constante de Michaelis-Menten, a curva de temperatura e $\mathrm{pH}$ e também o efeito de inibidores pode ser alterado quando a enzima está imobilizada.

Os principais fatores que influenciam a utilização do processo de imobilização enzimática são o custo da enzima; o custo da imobilização; a performance do sistema; e o custo de purificação da enzima.

Quanto ao suporte utilizado, deve-se avaliar a estabilidade da matriz e sua compatibilidade com a enzima e com o substrato. O suporte deve ser estável durante o processo para impedir o desprendimento da enzima e prevenir adulterações do produto, além disso, o suporte não pode ser tóxico.

As principais vantagens da técnica de imobilização de enzimas são a facilidade de remoção do biocatalisador a qualquer momento em que se deseje interromper a reação; a possibilidade de reutilização do biocatalisador; e a possibilidade de utilização de reato- 
res com alta concentração de enzimas, reduzindo o tempo de residência.

Essa técnica apresenta uma ampla variedade de utilizações médicas (CHANG, 1979), farmacêuticas (SWEIGART, 1979) e industriais (CHIBATA e TOSA, 1976). Alguns exemplos de seu uso estão descritos a seguir.

Imobilização de asparaginase para tratamento de leucemia (SIU CHONG e CHANG, 1974; CHANG, 1971), pois as células leucêmicas não sintetizam asparagina e com esse tratamento, morrem de inanição. A enzima tem que ser imobilizada pois sua administração não pode ser na sua forma livre devido a problemas de reações alérgicas. A fenilalanina amonia liase imobilizada reduziu o nível de fenilalanina em ratos com fenilcetonúria (BOURGET e CHANG, 1985).

$\mathrm{Na}$ indústria farmacêutica, a imobilização de enzimas já foi alvo de muitos trabalhos e algumas patentes. De 1954 a 1969, a Tanabe Seiyaku Co. operou processos de produção de L-aminoácido baseados no uso da aminoacilase, na forma livre (WANDREY, e FLASCHEL, 1979; CHIBATA et al, 1985), mas são de custo muito alto e a separação do produto é complicada, além de não poder reutilizar a enzima. Durante a década de 60 foram investigadas formas de resolver esses problemas através da imobilização da enzima aminoacilase. A produção industrial de L-metionina por aminoacilase imobilizada em DEAE-Sephadex foi a primeira utilização industrial em larga escala de enzima imobilizada feita pela Tanabe Seiyaku Co. em 1969. A vida média dessa enzima no reator é de aproximadamen- 
te 65 dias a temperatura de $50^{\circ} \mathrm{C}$ (TOSA et al, 1969).

$\mathrm{Na}$ área de antibióticos, diversas empresas utilizam essa técnica para produção de seus fármacos. Segundo BRODELIUS, 1978, muitas companhias farmacêuticas (BEECHAM, BAYER, SQUIBB e ASTRA) desenvolveram processos de imobilização da enzima penicilina amidase, responsável pela produção das penicilinas semi-sintéticas, os quais estão operando em escala industrial.

Industrialmente, em termos de quantidade, a produção de xarope de glicose a partir de amido é, talvez, a principal área da biocatálise. Toneladas de xarope de glicose são produzidas anualmente pela conversão de amido pela enzima amiloglucosidade (solúvel). Muitos trabalhos tentaram desenvolver um processo econômico baseado na imobilização de amiloglucosidase, mas ainda nada foi adotado comercialmente (SOLOMON, 1978; CONG et al, 1995; ZANIN e MORAES, 1995).

A enzima inulinase, obtida de diversos organismos, já foi imobilizada utilizando-se diversas técnicas, sempre com o objetivo de bioconverter a inulina em frutose ou inulo-oligossacarídeos menores (NAKAMURA et al, 1997).

A inulinase de Pseudomonas sp foi imobilizada por YUN et al, 1997, em vidro poroso. As condições ótimas de operação em um reator de produção contínua foram: concentração de $50 \mathrm{~g} / \mathrm{l}$ de inulina, velocidade de $1,1 \mathrm{l} / \mathrm{h}$ e temperatura de $50^{\circ} \mathrm{C}$. A meia vida da enzima nestas condições foi de 35 dias. 
FLORÊNCIO (1995) imobilizou a inulinase em diversos suportes, como a sílica, alginato e quitina, obtendo melhores resultados com a sílica, cujo rendimento de imobilização foi de $36 \%$. NAKAMURA et al, 1995, imobilizaram covalentemente a inulinase de Aspergilus niger em um derivado poroso de celulose (aminocelulofine). A taxa de imobilização foi de $96 \%$, e em uma coluna contendo $8 \mathrm{ml}$ do suporte ativo, uma solução de $5 \%$ de inulina foi completamente hidrolizada numa velocidade de $1 \mathrm{ml} / \mathrm{min}$ a $40^{\circ} \mathrm{C}$. O produto da reação foi uma mistura de $97 \%$ de D-frutose e $3 \%$ de D-glicose. GUPTA et al, 1990, imobilizaram a inulinase de Fusarium oxysporum em gel de poliacrilamida, retendo $45 \%$ de sua atividade inicial. A estocagem da enzima imobilizada a $25^{\circ} \mathrm{C}$ por 96 horas diminuiu sua atividade para $58 \%$. A inulinase de Aspergilus ficuum foi imobilizada em quitina tratada com glutaraldeído (KIM e RHEE, 1989). Em um reator de batelada, a hidrólise foi de $80 \%$ em 4 horas e de $90 \%$ em 10 horas com $400 \mathrm{ml}$ de extrato de $H$. tuberosus contendo $100 \mathrm{~g} / \mathrm{l}$ de carboidratos, com $20 \mathrm{~g}$ de quitina ativa. A hidrólise completa não foi atingida em 24 horas. A inulinase de $K$. marxianus foi imobilizada em 2-aminoetil-celulose tratada com glutaraldeído (KIM et al, 1992). Em um reator de batelada, a conversão da inulina de $H$. tuberosus foi de $90 \%$ em 20 horas, com solução de $7 \%$ de inulina e $28 \mathrm{ml}$ de enzima imobilizada. 


\section{MATERIAL E MÉTODOS}

\subsection{Extração de Inulina}

Como fonte de inulina foram utilizados tubérculos de Helianthus tuberosus cultivados na região de Piracicaba - SP, em solo arenoso, nos meses de janeiro a abril de 1996. A colheita foi realizada imediatamente após a senescência das flores e começo da secagem das folhas. Os tubérculos recém colhidos foram imediatamente processados, ou seja, foram lavados, selecionados e moídos em uma centrífuga da marca Arno, modelo Pro, série $A A$, para extração do caldo. Antes de serem moídos, os tubérculos foram submetidos a um tratamento térmico para inativação das enzimas inulinolíticas presentes na planta; após imersão em água em ebulição, foi interrompido o aquecimento e os tubérculos foram mantidos até o resfriamento desta. Foi realizado um teste em branco, isto é, foram moídos tubérculos sem tratamento térmico, para avaliação da eficiência do método. Durante a extração foi adicionado metabissulfito de sódio a $10 \mathrm{mg} / \mathrm{l}$ para evitar reações enzimáticas de escurecimento do caldo. O resíduo da centrifugação (bagaço) foi fervido, adicionando-se igual peso em água, para melhor extração da inulina. Para melhor purificação 
do extrato, fez-se necessária uma desproteinização, a qual foi realizada com adição de igual volume de etanol e deixando-se em repouso por 24 horas. Após esse tempo foi realizada uma destilação para retirada do etanol e para concentração do extrato.

Após esse processamento, o extrato foi quantificado quanto aos açúcares redutores totais (inulina) e mantido congelado.

\subsection{Obtenção e Extração da Inulinase}

Apesar do extrato de $H$. tuberosus ser um meio apropriado para a fermentação por $K$. marxianus, optou-se por um meio de cultura semi-sintético visando-se facilitar o processo de concentração e purificação da enzima.

Foi utilizada neste trabalho a linhagem da levedura $K$. marxianus MMIII-41, anteriormente melhorada geneticamente quanto à produção de inulinase. Essa linhagem é um híbrido diplóide, resultante de sucessivos cruzamentos, seguido de seleção, e apresenta uma hiper produção de inulinase, mesmo sem a indução da inulina no meio de cultura.

A inulinase foi produzida em meio de cultura YEPS líquido (extrato de levedura, peptona e sacarose). A cultura estoque (3.5.2) foi repicada em YEPD sólido (extrato de levedura, peptona e dextrose), e depois de 24 horas foi inoculada em frascos erlenmeyers de 1.000 $\mathrm{ml}$, com $500 \mathrm{ml}$ de meio de cultura, mantidos a $30^{\circ} \mathrm{C}$ sob agitação 
constante de $180 \mathrm{rpm}$ durante 5 dias.

Após o período de incubação, o meio fermentado foi centrifugado para eliminação das células e o sobrenadante foi concentrado em evaporador rotativo, sob pressão de $750 \mathrm{~mm} \mathrm{Hg}$ a 45 $48^{\circ} \mathrm{C}$. A concentração foi de cerca de 30 vezes, até formar um caldo viscoso. O meio concentrado foi submetido à uma diálise para eliminação de sais e açúcares presentes.

\subsection{Soluções}

\subsubsection{Solução Tampão de Inulina}

Solução contendo $0,1 \%$ de inulina, dissolvida a quente em tampão citrato-fosfato $\mathrm{pH} 7,0$. Essa solução foi utilizada como substrato para medida da atividade enzimática da inulinase.

\subsubsection{Solução Padrão de AR}

Para a correlação dos valores de absorbância obtidos na análise de açúcares de Somogy e Nelson foi utilizada uma solução padrão de 50 mg/l de AR. Para tanto, preparou-se uma solução estoque da seguinte maneira:

- deixar a sacarose P.A. em dessecador por 24 horas sob vácuo; 
- dissolver $10,0 \mathrm{~g}$ de sacarose em $100 \mathrm{ml}$ de água destilada em balão volumétrico de $1.000 \mathrm{ml}$;

- gotejar $5 \mathrm{ml}$ de $\mathrm{HCl}$ concentrado, vagarosamente e sob agitação;

- deixar em repouso durante 3 dias a temperatura ambiente para ocorrer a hidrólise ácida;

- neutralizar até pH 3,0 com $\mathrm{NaOH} 1 \mathrm{~N}$ no início e $0,1 \mathrm{~N}$ no final;

- adicionar $2 \mathrm{~g}$ de ácido benzóico dissolvidos anteriormente em $200 \mathrm{ml}$ de água quente (o ácido benzóico inibe o crescimento microbiano);

- completar o volume para um litro;

- guardar em geladeira.

Essa solução estoque, com $1 \%$ de AR, é diluída em 10 vezes e em seguida em 20 vezes no momento da análise, ficando com $50 \mathrm{mg} / \mathrm{l}$.

\subsection{Meios de Cultura}

Os meios de cultura foram preparados com água destilada e esterilizados em autoclave a $121^{\circ} \mathrm{C}$ por $20 \mathrm{~min}$, em frascos erlenmeyers. 


\subsubsection{YEPS}

Extrato de Levedura ................... 1,0\%

Peptona ...................................... 1,0\%

Sacarose .................................... 2,0\%

Ágar (somente para meio sólido). 2,0\%

$\mathrm{O} \mathrm{pH}$ deve estar em torno de 6,5 a 6,8.

\subsubsection{Meio de Extrato de $H$. tuberosus}

Após a extração do caldo, desproteinização e medição do ART, foi feita uma diluição do extrato para $2 \%$ de ART. Em seguida foram adicionados $1 \%$ de peptona e $1 \%$ de extrato de levedura, como fontes de nitrogênio. $\mathrm{O} \mathrm{pH}$ foi ajustado para $6,8 \mathrm{com} \mathrm{NaOH} 1 \mathrm{~N}$. Desse modo:

Extrato de $H$. tuberosus .............. 2\% ART
Peptona .................................... 1\%
Extrato de levedura..................... 1\%

\subsection{Procedimentos}

\subsubsection{Cultura - Estoque}

A linhagem MMIII-41 foi armazenada de duas maneiras 
distintas, uma (a) para a sua utilização a curto prazo e a outra, para sua utilização a longo prazo (b).

a) - preparação de meio YEPD sólido;

- adição de $3 \mathrm{ml}$ do meio em tubo de ensaio pequeno;

- esterilização (3.5.1);

- após a autoclavagem, os tubos são retirados ainda quentes e mantidos inclinados até a solidificação do ágar;

— inoculação da linhagem (3.5.3);

— incubação a $30^{\circ} \mathrm{C}$ por 24 horas em BOD (sem agitação);

- adição de nujol estéril até cobrir o meio de cultura;

- armazenagem sob refrigeração $\left(8^{\circ} \mathrm{C}\right)$.

b) - preparação de meio YEPD líquido;

- adição de $3 \mathrm{ml}$ do meio em tubo de ensaio;

- esterilização;

— inoculação da linhagem;

- incubação a $30^{\circ} \mathrm{C}$ por 24 horas em BOD;

— preparação de solução $30 \%$ de glicerol em água destilada;

- esterilização da solução;

- em um "eppendorf", adicionar $500 \mu \mathrm{l}$ do meio de cultu-

ra fermentado e $500 \mu$ da solução de glicerol;

- agitar para homogenização;

- armazenagem a $-70^{\circ} \mathrm{C}$. 


\title{
3.5.2. Inoculação da Linhagem
}

\begin{abstract}
A inoculação da linhagem MMIII-41 nos meios de cultura foi realizada em uma câmara de fluxo laminar, previamente higienizada com álcool comercial. A transferência do material biológico foi feita com auxílio de um palito do tipo português esterilizado, coletando-se as células e as transferindo para o meio desejado.
\end{abstract}

\subsubsection{Hidrólise Ácida da ínulina}

Para a quantificação dos ART de uma solução contendo inulina (extrato de $H$. tuberosus ou tampão de inulina), a mesma foi submetida a uma hidrólise ácida e o AR liberado foi quantificado segundo metodologia de Somogy e Nelson. Para tanto, depois de realizadas as devidas diluições da amostra, foi coletado $1 \mathrm{ml}$ e adicionado em um balão volumétrico de $100 \mathrm{ml}$. Em seguida foram adicionados $2 \mathrm{ml}$ de solução $0,1 \mathrm{~N}$ de $\mathrm{HCl}$, tampado o balão, e incubado em banho-maria a $65^{\circ} \mathrm{C}$ sob agitação por $1 \mathrm{~h}$. Após essa incubação, 0 frasco foi resfriado em água corrente e o ácido foi neutralizado com 2 $\mathrm{ml}$ de $0,1 \mathrm{~N}$ de $\mathrm{NaOH}$. O balão volumétrico foi completado a $100 \mathrm{ml}$ com água destilada e o AR foi quantificado. 


\subsubsection{Análise de Açúcares Redutores}

Para a análise de açúcares redutores foi utilizada a metodologia de Somogy e Nelson, descrita por LAGUNA, 1986.

\subsubsection{Análise da Atividade Enzimática}

A avaliação da atividade inulinolítica de uma amostra foi realizada através da quantificação do $A R$ formado pela hidrólise enzimática da inulina pelo método de Somogy e Nelson. O procedimento segue-se como descrito a seguir:

- realizam-se as devidas diluições da amostra;

- $5 \mathrm{ml}$ de tampão de inulina são colocados em um tubo de ensaio e posto em banho-maria a $45^{\circ} \mathrm{C}$;

- $1 \mathrm{ml}$ da amostra diluída é acrescentada ao tubo após a estabilização da temperatura;

- após 10 minutos de incubação, rapidamente coleta-se $1 \mathrm{ml}$ da solução com auxílio de uma micropipeta;

- transfere-se essa amostra para um tubo de ensaio, previamente marcado (tubo A, amostra $\mathrm{x}$ ) e acrescido de $1 \mathrm{ml}$ de reagente de Somogy;

- então, seguem-se os procedimentos da análise de Somogy e Nelson.

Concomitantemente é realizada uma prova em branco para 
cada amostra para a quantificação do AR que já estava presente na amostra, o qual não é resultado de hidrólise enzimática. Para tanto, incuba-se a amostra diluída por 5 minutos em água fervente para inativação das enzimas e são acrescentados $5 \mathrm{ml}$ de tampão de inulina. Transfere-se $1 \mathrm{ml}$ dessa solução em um tubo previamente marcado (tubo B, amostra x) e acrescido do reagente de Somogy. Então, seguem-se os mesmos procedimentos descritos para o tubo $A$.

Para se obter a atividade enzimática a partir da leitura de densidade óptica, temos as seguintes fórmulas:

$$
\begin{array}{r}
F=\frac{50 \times 6}{10 \times 180} \times D \\
\text { Atividade }=\frac{A-B}{P} \times F
\end{array}
$$

onde: $\quad F=$ fator

$$
50 \text { = padrão de } 50 \mathrm{mg} / \mathrm{l} \text { de glicose; }
$$

6 = diluição da amostra $(1 \mathrm{ml}$ de amostra e $5 \mathrm{ml}$ de tampão de inulina;

10 = tempo de reação em minutos;

$180=$ peso molecular da glicose

D = diluição da amostra

$A$ = leitura de absorbância do tubo A (reação com inulina); 


$$
\begin{aligned}
B= & \text { leitura de absorbância do tubo } B \text { (branco da reação); } \\
P= & \text { leitura de absorbância do tubo padrão } 50 \text { ppm de } \\
& \text { glicose. }
\end{aligned}
$$

A unidade é em $\mu \mathrm{mol} \mathrm{AR} / \mathrm{min} / \mathrm{ml}$ ou Unidades $(U)$ da enzi$\mathrm{ma} / \mathrm{ml}$.

\subsubsection{Análise de Proteínas pelo Método do Biureto}

Para a análise de proteínas das soluções, foi utilizado o método do biureto descrito por HERBERT et al, 1971 modificado.

Para a realização das análises foi utilizado um termociclador PT 100 para a geração de calor e a leitura foi feita com um espectrofotômetro a $555 \mathrm{~nm}$. O procedimento foi feito de acordo como segue:

- 300 $\mu \mathrm{l}$ da amostra foram colocados em um "eppendorf", com auxílio de uma micropipeta;

- foram adicionados $150 \mu \mathrm{l}$ de $\mathrm{NaOH} 3,0 \mathrm{~N}$;

- incubação a $100^{\circ} \mathrm{C}$ por 5 minutos;

- esfriar no gelo;

- adicionar $150 \mu \mathrm{l}$ de $\mathrm{CuSO}_{4}$ 2,5\%;

- agitar;

- centrifugar por 5 minutos a $3.000 \mathrm{~g}$;

- leitura a $555 \mathrm{~nm}$. 


\subsection{Métodos de Imobilização de Enzimas}

Os suportes de imobilização de enzimas foram escolhidos por sua simplicidade e custo, sendo de fácil obtenção, manejo, custos reduzidos, não tóxicos e compatíveis com o substrato e com o meio de hidrólise. Com exceção da pectina, todos os suportes são compatíveis também com a solução enzimática utilizada.

\subsubsection{Imobilização em Quitina}

Foi utilizada neste ensaio quitina de lagosta, cedida pelo Prof. Dr. Afrânio Garcia (PADETEC - UFC, Parque de Desenvolvimento Tecnológico da Universidade Federal do Ceará).

A quitina foi preparada realizando-se uma desmineralização a $20^{\circ} \mathrm{C}$ com $22 \%$ de $\mathrm{HCl}$ seguida de uma desproteinização com $28 \%$ de $\mathrm{KOH}$ a $90^{\circ} \mathrm{C}$. A quitina foi então moída e peneirada em malha de 0,58 mesh (SYNOWIECKI et al, 1987).

A imobilização foi realizada com $1 \mathrm{~g}$ de quitina incubada em $5 \mathrm{ml}$ de solução enzimática com um total de $178 \mathrm{U}$ da enzima, a pH 7,0 sob agitação constante durante 24 horas.

O teste com glutaraldeído foi realizado da mesma forma, com ativação da quitina com $2 \%$ de glutaraldeído em tampão citratofosfato $\mathrm{pH} \mathrm{4,5}$ durante 1 hora, seguido de 3 lavagens com água destilada para remoção do excesso. 
Após o período de incubação, foi avaliado o grau de imobilização através de um método indireto, medindo a atividade enzimática do sobrenadante e comparada com a atividade inicial. Essa diferença indica a perda de atividade devido à imobilização ou inativação da enzima, por vários motivos. A quitina foi lavada com tampão citrato-fosfato $\mathrm{pH} 7,0$ por 3 vezes para remoção do excesso de enzima não imobilizada no suporte.

Com a obtenção desse suporte cataliticamente ativo, foi construída uma coluna para avaliação do processo. A quitina foi acondicionada em uma coluna de $0,5 \mathrm{~cm}$ de diâmetro interno. Na parte inferior da coluna, foi colocado algodão hidrofóbico para impedir que a quitina se escoasse. Ao redor dessa coluna foi colocada uma jaqueta, com circulação de água a temperatura controlada de $45^{\circ} \mathrm{C}$ (Figura 8). A velocidade de passagem do substrato (solução tampão de inulina) foi controlada por uma bomba peristáltica colocada na parte inferior da coluna, e foi de $200 \mu \mathrm{l} / \mathrm{min}$ de tempo de residência. A coleta do material submetido a hidrólise foi realizada em intervalos de 30 minutos em um tubo de ensaio, sendo que, ao se atingir um pouco mais de $1 \mathrm{ml}$ de produto, o mesmo era imediatamente coletado com uma micropipeta graduada para $1 \mathrm{ml}$ e transferido para um tubo com $1 \mathrm{ml}$ do reagente de Nelson. Esse procedimento foi necessário para que, caso a enzima fosse se desprendendo do suporte (quitina), a reação enzimática não continuaria dentro do tubo (o reagente de $\mathrm{Nel}$ son paraliza a reação de hidrólise), interferindo na avaliação da coluna. 
A coleta a cada 30 minutos foi realizada para verificar se a atividade diminuia conforme o substrato fosse passando pela coluna, devido ao desprendimento da enzima do suporte, ou por exaustão do processo.

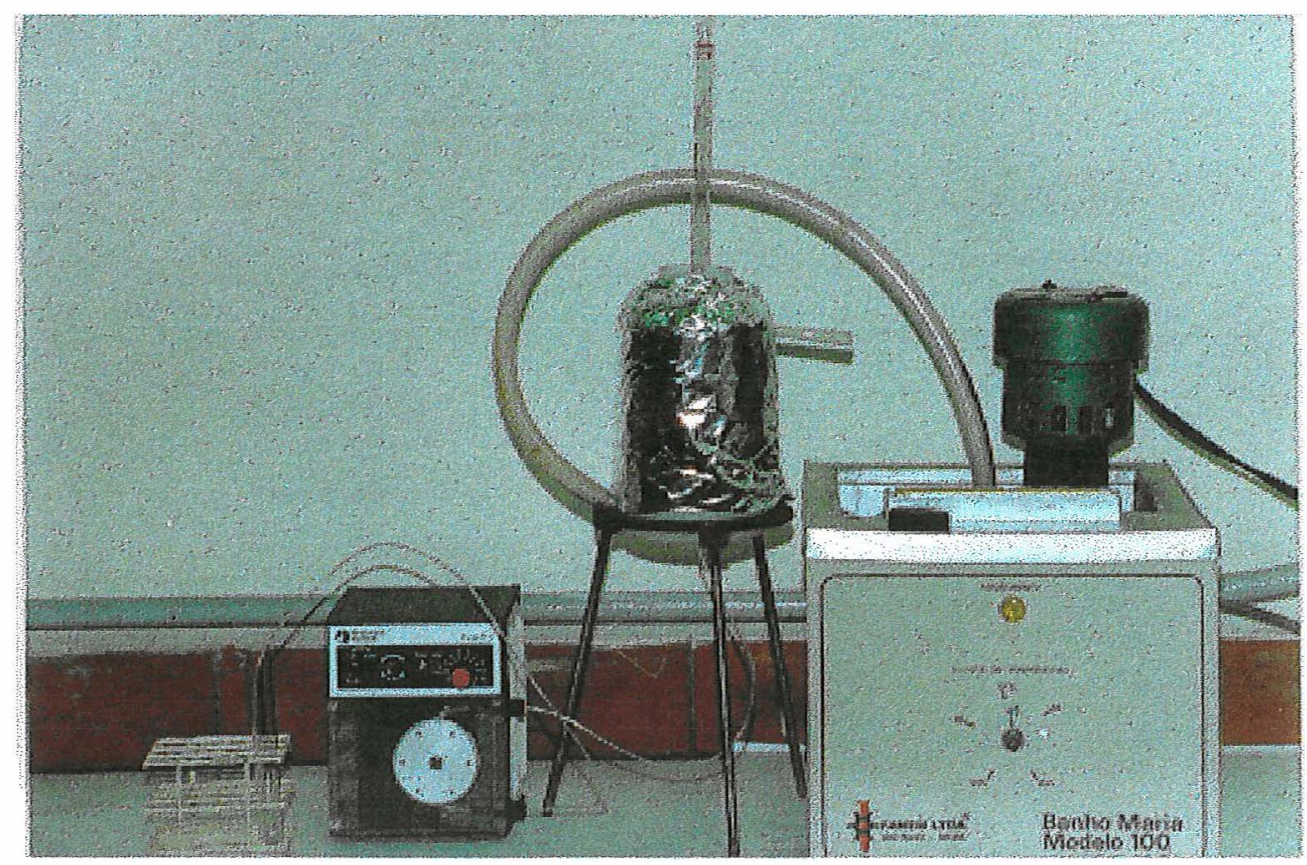

Figura 8. Coluna de imobilização em quitina.

\subsubsection{Imobilização em Alginato de Sódio}

Foram utilizadas duas concentrações de alginato de sódio para os ensaios de imobilização: $2 \%$ e $4 \%$. Neste trabalho, foram utilizados $20 \mathrm{ml}$ de solução enzimática, totalizando $712 \mathrm{U}$ da inulinase, acrescentando-se $0,4 \mathrm{~g}$ de alginato de sódio (2\%) e 0,8g (4\%). Essa mistura deve ser feita muito devagar e sob agitação leve, a fim de se evitar a formação de corpos muito densos, os quais não mais se dissolvem, acarretando em uma mistura heterogênea quanto a concen- 
tração de alginato.

Em seguida, essa suspensão é gotejada, com auxílio de uma micropipeta, em uma solução de $4 \%$ de $\mathrm{CaCl}_{2}$ sob agitação. Imediatamente após a gota entrar em contato com a solução, ocorre a gelatinização, formando-se uma pérola de aproximadamente $3 \mathrm{~mm}$ de diâmetro. As pérolas foram mantidas na solução de $\mathrm{CaCl}_{2}$ por 1 hora a fim de que o $\mathrm{Ca}^{+2}$ se difundisse até o interior do gel, tornando esse suporte mais consistente.

Foram realizadas sucessivas lavagens com tampão citratofosfato pH 7,0 para eliminação do excesso de enzima do gel, até não mais ser detectada atividade enzimática no tampão de lavagem.

A avaliação da imobilização foi feita com $20 \mathrm{~g}$ de suporte cataliticamente ativo em $50 \mathrm{ml}$ de tampão de inulina a $45^{\circ} \mathrm{C}$ sob agitação. Periodicamente foram coletadas amostras para quantificação de $A R$, resultante da hidrólise enzimática da inulina.

\subsubsection{Imobilização em Pectina}

A preparação do gel de pectina seguiu os mesmos procedimentos aplicados ao alginato de sódio, entretanto, não foi possível a obtenção de um gel de pectina com a solução enzimática (4.7). 


\subsubsection{Contenção da Inulinase em Membrana de Diálise}

A enzima inulinase foi contida em uma membrana de diálise. Tanto a enzima quanto a inulina não atravessam a membrana, somente os monossacarídeos (gerados pela hidrólise da inulina). Dessa forma, foi dimensionado um sistema utilizando-se 8 metros de membrana de diálise de $1 / 4$ " de diâmetro.

O tubo de membrana foi acondicionado na forma de uma espiral em um tubo feito com tela (para que ocorra diálise também na parte interna da espiral). Esse sistema foi colocado no interior de um tubo de acrílico cheio de água para proporcionar a diálise. Em um banho-maria a $45^{\circ} \mathrm{C}$ ocorre a reação enzimática de hidrólise da inulina; com auxílio de uma bomba peristáltica, essa solução é bombeada para o início do tubo de membrana, circulando por toda sua extensão e retornando ao banho-maria (Figura 9). Dessa forma, a enzima não é perdida durante o processo.

Foram utilizados $500 \mathrm{ml}$ de extrato de $H$. tuberosus com $17 \%$ de ART e $1 \%$ de AR. Esse extrato foi acondicionado em banhomaria a $45^{\circ} \mathrm{C}$ e, após a estabilização da temperatura, foi adicionado $1 \mathrm{ml}$ de solução enzimática com $50 \mathrm{U}$ da inulinase e iniciado a diálise com $4.000 \mathrm{ml}$ de água destilada. 


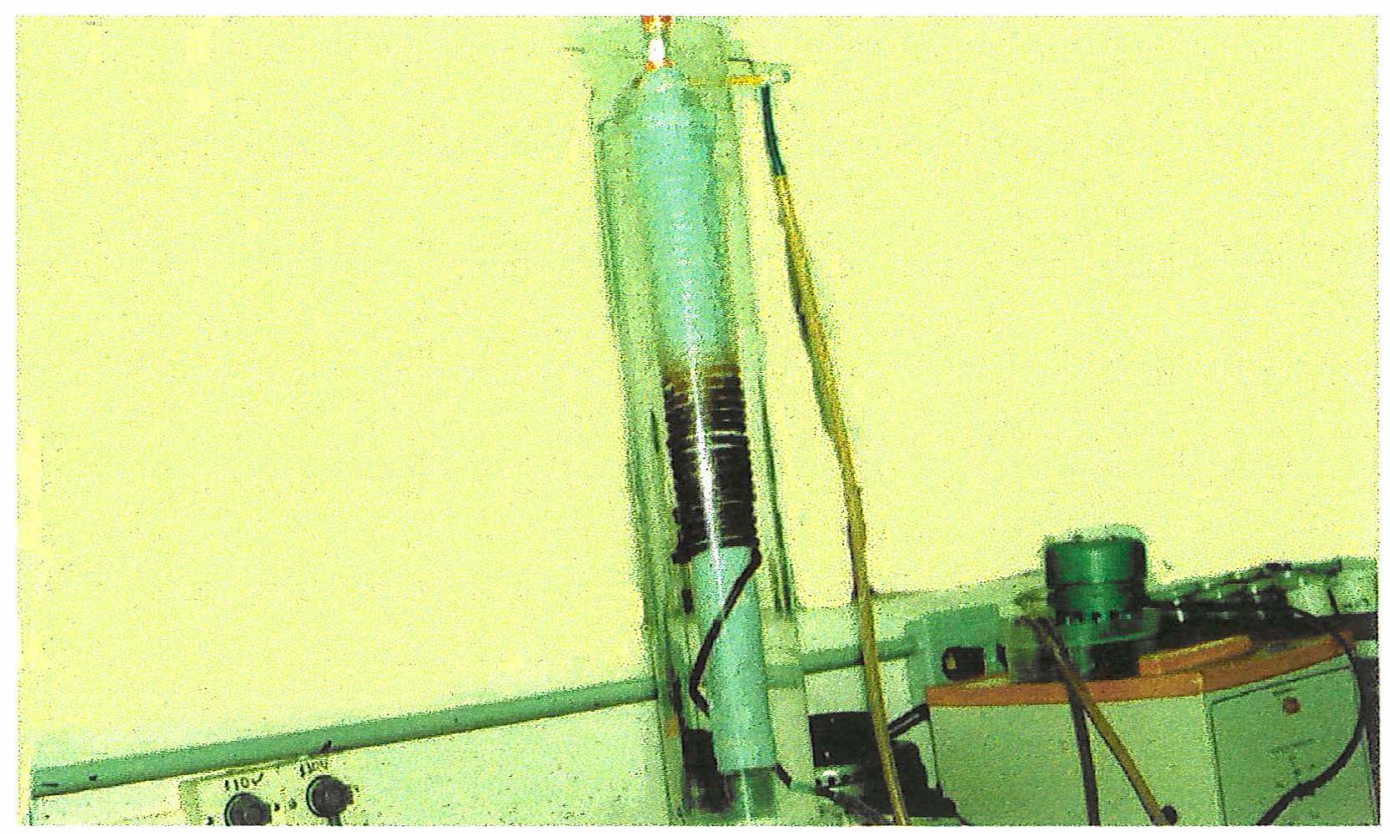

Figura 9. Contenção da inulinase em membrana de diálise.

\subsubsection{Imobilização em Sílica de Porosidade Controlada (SPC)}

Foi utilizada sílica de porosidade de 180-250 $\mu \mathrm{m}$, cedida pelo Prof. Dr. Henrique Celso Trevisan, do Instituto de Química da Unesp - Araraquara. A imobilização em sílica envolveu as etapas de limpeza da SPC; silanização da SPC; ativação com glutaraldeído; e imobilização da inulinase (Figura 10).

\subsubsection{Limpeza da SPC}

- Pesaram-se $2 \mathrm{~g}$ de sílica de porosidade de 180-250 
$\mu \mathrm{m}$ em um tubo com rolha;

- adicionaram-se $10 \mathrm{ml}$ de solução $10 \% \mathrm{HNO}_{3}$;

— incubação em água fervente por 1 hora;

- o material foi filtrado e lavado com água destilada;

- secagem a $115^{\circ} \mathrm{C}$ durante 12 horas.

\subsubsection{Silanização da SPC}

A superfície da sílica foi silanizada através da reação com o $\gamma$-amino propil trietoxi silano ( $\gamma$-APTS) originando um derivado com grupo amino livre para a reação com o glutaraldeído. O procedimento foi o seguinte:

- pesou-se $1 \mathrm{~g}$ de sílica em um tubo de $15 \mathrm{ml}$ com fundo cônico;

- adicionou-se $1 \mathrm{ml}$ de solução $0,5 \%$ de $\gamma$-APTS pH 3,5;

- o tubo foi colocado em uma câmara de vácuo por 15 minutos a $760 \mathrm{~mm} \mathrm{Hg}$, para que a solução penetre pelos microporos da sílica;

— agitação a $75^{\circ} \mathrm{C}$ por 3 horas;

- o sobrenadante foi removido com uma pipeta pasteur descartável;

- 3 lavagens com água destilada, seguido pela retirada do sobrenadante, para remoção do excesso de $\gamma$-APTS;

- secagem em estufa a $100^{\circ} \mathrm{C}$ por 12 horas. 


\subsubsection{Ativação com Glutaraldeído}

- Pesaram-se $200 \mathrm{mg}$ de sílica silanizada seca em um tubo de $15 \mathrm{ml}$ com fundo cônico;

— adicionaram-se $2 \mathrm{ml}$ de solução $2,5 \%$ de glutaraldeído em tampão acetato pH 4,5 (ideal para a ligação sílica-glutaraldeido);

- o tubo foi colocado em uma câmara de vácuo por 15 minutos a $760 \mathrm{~mm} \mathrm{Hg}$ para que a solução penetre pelos microporos da sillica;

— incubação a temperatura ambiente por 1 hora;

- o sobrenadante foi removido com uma pipeta pasteur descartável;

- 3 lavagens com água destilada, seguido pela retirada do sobrenadante, para remoção do excesso de glutaraldeído.

\subsubsection{Imobilização da Inulinase}

- A SPC ativada foi lavada 3 vezes com tampão fosfato 6,6 ( $\mathrm{pH}$ ideal para a ligação glutaraldeído - enzima);

- adição de $500 \mu l$ de solução enzimática com um total de 9,3U da enzima;

— incubação por 24 horas sob refrigeração;

- uma alíquota do sobrenadante dessa mistura foi coletada para análise da atividade enzimática; 
- 3 lavagens com tampão fosfato $\mathrm{pH} 7,0(\mathrm{pH}$ ótimo da enzima) para remoção do excesso de enzima.

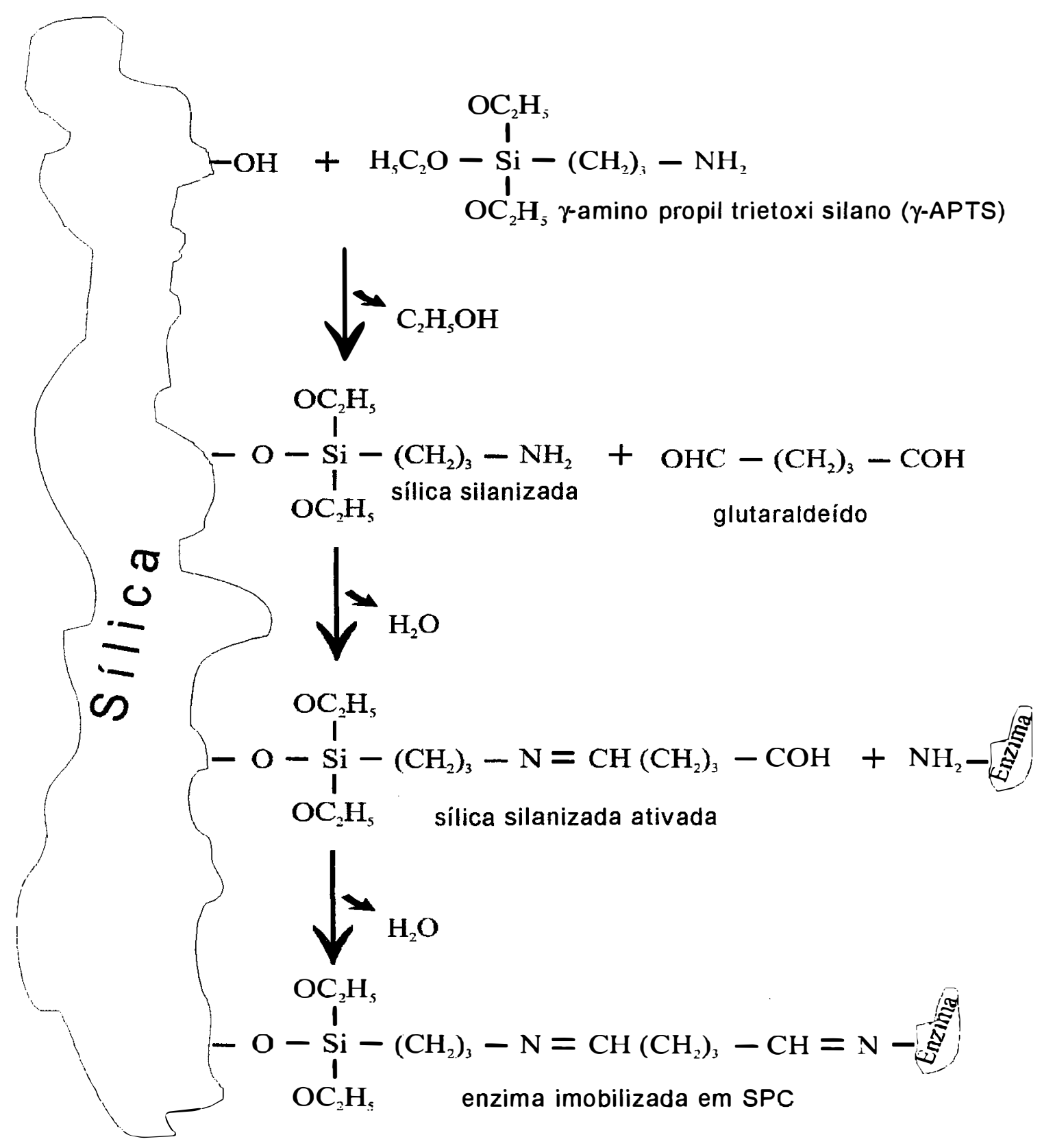

Figura 10. Esquema de imobilização de enzimas em SPC. 


\section{RESULTADOS E DISCUSSÃO}

A inulina presente nos tubérculos de $H$. tuberosus foi extraída, clarificada, concentrada e analisada quanto ao teor de açúcares.

A inulinase foi produzida, concentrada e utilizada nos experimentos de imobilização, onde foram avaliados a performance do sistema, a compatibilidade com o suporte e, no caso da SPC, a curva característica de $\mathrm{pH}$ e temperatura.

\subsection{Extração da Inulina}

A concentração de açúcares redutores totais presente no extrato de $H$. tuberosus obtido por centrifugação dos tubérculos, foi de $15 \%$. O extrato obtido pela fervura do bagaço apresentou uma concentração de $2 \%$ em ART (3.1). Do total extraído, verificou-se que $1 \%$ dos açúcares totais eram redutores, o que demonstra que a inulina se apresentava praticamente intacta. $O$ tratamento térmico realizado anteriormente à centrifugação (3.1) não demonstrou nenhuma diferença para com a testemunha. A extração não foi melhorada (relação entre peso dos tubérculos antes do cozimento e quantidade de ART extraída) e a qualidade da inulina também não foi alterada devi- 
do à inativação das enzimas endógenas da planta, visto que a concentração de AR não sofreu alterações com o tratamento, e também não foi observada nenhuma facilidade na moagem. Desse modo, não se faz necessária essa etapa no processamento dos tubérculos.

O teor de proteína do extrato clarificado (3.1) apresentou os seguintes resultados:

A concentração de proteínas inicial do extrato foi de $15 \mathrm{mg} /$ $\mathrm{ml}$, e a clarificada foi de $6 \mathrm{mg} / \mathrm{ml}$. Entretanto, valores mais significativos são dados em g ART/g proteína, devido à concentração do extrato por destilação para retirada do etanol. Inicialmente tinham-se 150 $\mathrm{g} / \mathrm{l}$ de ART e $15 \mathrm{~g} / \mathrm{l}$ de proteína, ou seja $10 \mathrm{~g} \mathrm{ART/g}$ proteína e após a clarificação, $250 \mathrm{~g} / \mathrm{l}$ de ART e $6 \mathrm{~g} / \mathrm{l}$ de proteína, ou seja, $42 \mathrm{~g}$ de ART/ g proteína, indicando um rendimento de $76 \%$ de retirada de proteína com o tratamento.

Industrialmente o etanol necessário para esse processo pode ser obtido na própria unidade, com a fermentação do extrato de $H$. tuberosus pela levedura $K$. marxianus, o que, bem dimensionado, poderia reduzir custos; o calor gerado na destilação para retirada do álcool serve também para a concentração do extrato, favorecendo a etapa de armazenagem em congelador, devido ao menor volume; a perda de açúcares devido à clarificação foi de $5 \%$, entretanto, ao final do processo, a concentração do extrato clarificado foi de $25 \%$ devido à concentração por destilação. KIM \& KIM, 1992, trabalharam com extrato de $H$. tuberosus com concentração de $20 \%$ de ART; esse 
processamento não alterou a relação $A R / A R T$, que permaneceu em torno de $1 \%$. A destilação não foi suficientemente drástica para causar danos à inulina, pois caso houvessem quebras nesse polímero, aumentaria a quantidade de açúcares redutores em relação aos totais. O resíduo da extração da inulina, tanto o bagaço resultado da centrifugação como a borra gerada pela clarificação podem ser utilizados para ração animal.

\subsection{Produção de Inulinase}

Após a centrifugação para eliminação das células do meio de cultura fermentado, este foi concentrado em evaporador rotativo (3.2). A duração desse processo foi de aproximadamente 4 horas. Ocorreu uma perda de atividade enzimática de $13 \%$ para uma concentração de aproximadamente 30 vezes, até formar um caldo viscoso.

Após a concentração, foi realizada uma diálise para eliminação de sais, açúcares e pigmentos do extrato enzimático. A diálise foi feita em membrana de 3/4" durante 6 horas em água corrente. Não foram detectadas melhorias na atividade enzimática após a diálise, sugerindo que a alta concentração de sais e açúcares no meio não causa interferências com a enzima. 


\subsection{Características da Inulinase na Forma Livre}

O perfil da atividade inulinolítica em função do $\mathrm{pH}$ e temperatura, com a enzima em sua forma livre, pode ser observado nas Figuras 11 e 12:

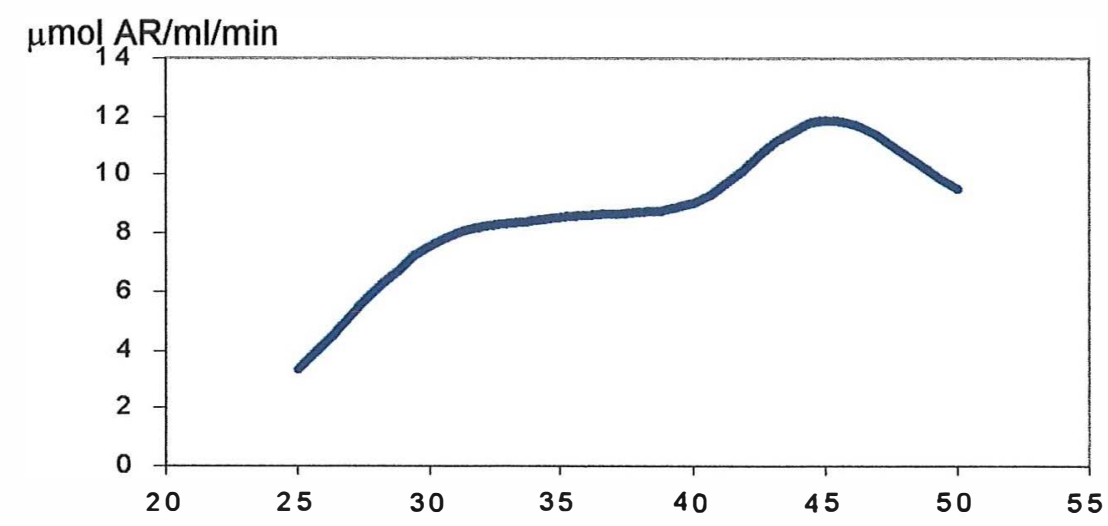

${ }^{\circ} \mathrm{C}$

Figura 11. Curva característica de atividade em função da temperatura da inulinase em sua forma livre, num substrato $1 \mathrm{~g} / \mathrm{l}$ inulina por $10 \mathrm{~min}$.

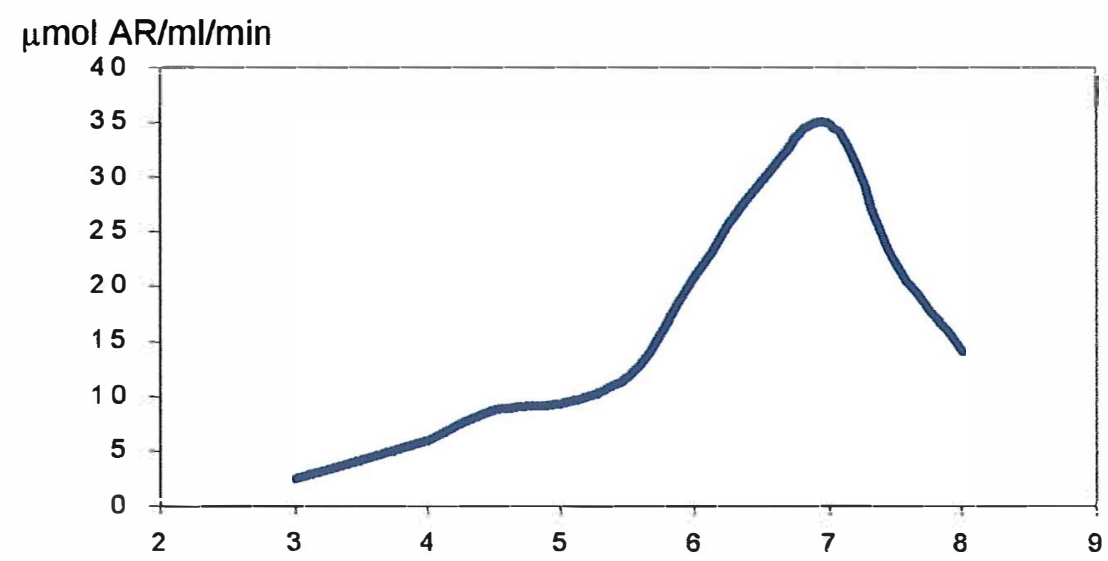

$\mathrm{pH}$

Figura 12. Curva característica de atividade em função do $\mathrm{pH}$ na temperatura de $45^{\circ} \mathrm{C}$ da inulinase em sua forma livre, num substrato $1 \mathrm{~g} / \mathrm{l}$ inulina por $10 \min$. 
Nota-se, dessa forma, que a temperatura ótima de reação enzimática é de $45^{\circ} \mathrm{C}$ e o pH ótimo é de 7,0 .

\subsection{Imobilização em Quitina}

A imobilização da inulinase em quitina (3.6.1) pôde ser confirmada através da análise enzimática do sobrenadante da mistura quitina + extrato enzimático. Após o processo de imobilização, o sobrenadante apresentou $130 \mathrm{U}$ da enzima, das 178 utilizadas na imobilização, sugerindo que $48 \mathrm{U}$ da inulinase foram imobilizadas e/ ou inativadas durante o processo. Dessa forma, a taxa de imobilização foi de $48 U / g$ de quitina.

Foram realizadas cinco coletas, em intervalos de $30 \mathrm{~min}$, obtendo os seguintes resultados, na ordem em que foram obtidos: $20,15,18,18$ e $17 \mu \mathrm{g} / \mathrm{l}$ de AR obtidos a partir da hidrólise enzimática da inulina.

Como o tampão de inulina utilizado apresenta uma concentração de $100 \mathrm{mg} / \mathrm{l}$, consideramos o desempenho da coluna muito baixo, visto que, com um tempo de residência do substrato com a enzima de $5 \mathrm{~min}$, somente $0,2 \%$ da inulina foi hidrolizada.

A imobilização com quitina tratada com glutaraldeído apresentou, na análise do sobrenadante, $95 \mathrm{U}$ da enzima, das $178 \mathrm{U}$ usadas, indicando uma maior imobilização, quando comparada com o tratamento sem glutaraldeído. Assim, a taxa de imobilização foi de 
$73 \mathrm{U} / \mathrm{g}$ de quitina. Entretanto a avaliação do desempenho da coluna resultou nos seguintes valores, na ordem em que foram obtidos: 14, 17, 11, 15 e $19 \mu \mathrm{g} / \mathrm{l}$ AR obtidos a partir da hidrólise enzimática da inulina.

O desempenho de ambas as colunas foi considerado muito baixo, sendo que, desse modo, a quitina foi descartada como suporte para imobilização da inulinase de K. marxianus.

\subsection{Imobilização em Alginato de Sódio}

A avaliação da imobilização em alginato, para ambas as concentrações testadas, pode ser observada na Figura 13.

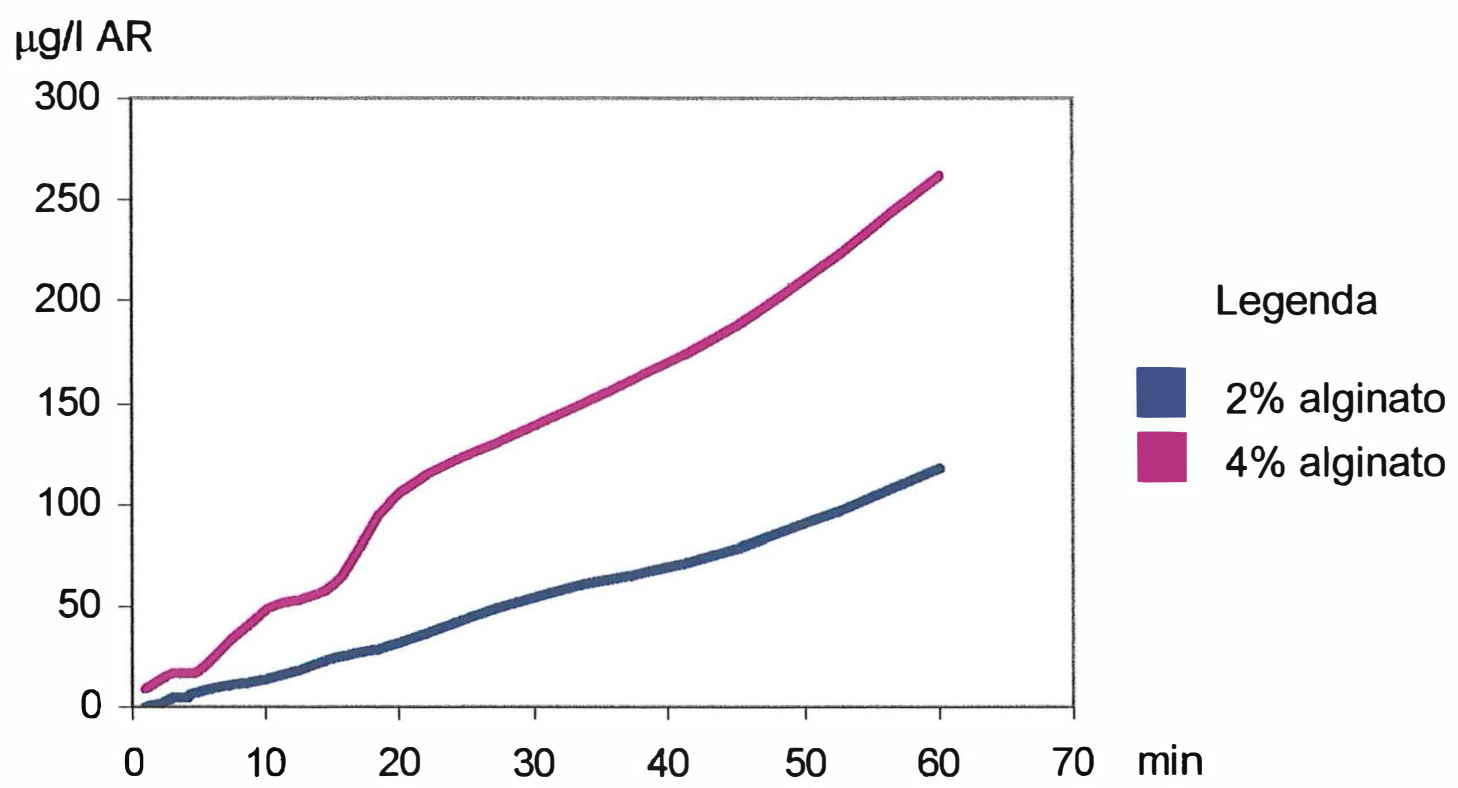

Figura 13. Tempo de incubação da inulinase imobilizada em alginato, em duas concentrações, pela formação de AR resultante da hidrólise enzimática da inulina. 
A eficiência da coluna aumentou consideravelmente com o aumento da concentração do gel, indicando um melhor aprisionamento da enzima. Entretanto, a eficiência desse sistema é demasiadamente baixo, pois, com $20 \mathrm{~g}$ de suporte em $50 \mathrm{ml}$ de substrato, após 1 hora de incubação, $12 \%$ do substrato foi convertido no gel sem glutaraldeído e $26 \%$ no gel com glutaraldeído.

Desse modo, o gel de alginato de sódio foi, nesse trabaIho, descartado como suporte da inulinase.

\subsection{Imobilização em Pectina}

A imobilização da inulinase em gel de pectina foi impossibilitada devido a não formação de um gel. Tentou-se aumentar a concentração de pectina, a qual chegou a um valor de até $15 \%$, sendo que $2 \%$ de pectina em água foram suficientes para formação de gel.

Devido a esse fato, o extrato enzimático foi avaliado e detectou-se a presença de uma atividade elevada de pectinase.

Dessa forma, descartou-se a pectina como suporte, prevendo as dificuldades, do ponto de vista industrial, de se purificar a inulinase para eliminação completa da pectinase.

\subsubsection{Determinação da Atividade Pectinolítica no Extrato Enzimático}

Foi medida a atividade pectinolítica do extrato enzimático 
e comparada com a pectinase comercial da NOVO quantificando os AR gerados na quebra dos polímeros, seguindo a mesma metodologia usada para a atividade inulinolítica. A análise de proteínas (3.5.7) dos extratos e a atividade pectinolítica realizadas em três repetições, pode ser observada na Tabela 1.

Tabela 1. Correlação entre a concentração de proteínas no extrato enzimático da Novo e da K. marxianus e Unidades de pectinase.

\begin{tabular}{l|ccc} 
& Proteína $(\mathrm{mg} / \mathrm{ml})$ & U pectinase $/ \mathrm{ml}$ & U pectinase/g prot. \\
\hline NOVO & 357 & 42 & 0,12 \\
K. maxianus & 116 & 56 & 0,48 \\
\hline
\end{tabular}

Apesar da concentração em proteínas do extrato enzimático da linhagem MMIII-41 ser menos da metade da comercial, sua atividade pectinolítica foi consideravelmente maior.

\subsection{Contenção da Inulinase em Membrana de Diálise}

$\mathrm{Na}$ Tabela 2 relacionou-se o tempo, a concentração de AR na solução fora do tubo de diálise, a quantidade em gramas de AR que atravessou a membrana e o AR na solução a ser feita a diálise (inulina que foi hidrolizada pela inulinase): 
Tabela 2. Correlação entre o tempo de diálise e a \% AR que atravessou a membrana; o volume da solução de diálise e o total de AR recuperado ( $\%$ AR $\times$ Volume).

\begin{tabular}{lcccc}
\hline Horas & $\begin{array}{c}\text { \% AR fora da } \\
\text { membrana }\end{array}$ & $\begin{array}{c}\text { Vol. do dializado } \\
(\mathrm{ml})\end{array}$ & $\begin{array}{c}\text { g de AR } \\
\text { recuperados }\end{array}$ & $\begin{array}{c}\text { AR do extrato } \\
(\%)\end{array}$ \\
\hline 0 & 0 & 4.000 & 0 & 1 \\
0,25 & 0,05 & $"$ & 2 & 6 \\
1 & 0,19 & $"$ & 7,5 & 10,6 \\
2 & 0,43 & $"$ & 11 & 9,9 \\
4 & 0,78 & $"$ & 31 & 11,8 \\
6 & 1,05 & $"$ & 42 & 9,4 \\
\hline
\end{tabular}

Na figura 14 observa-se a quantidade de AR recuperado por diálise em função do tempo.

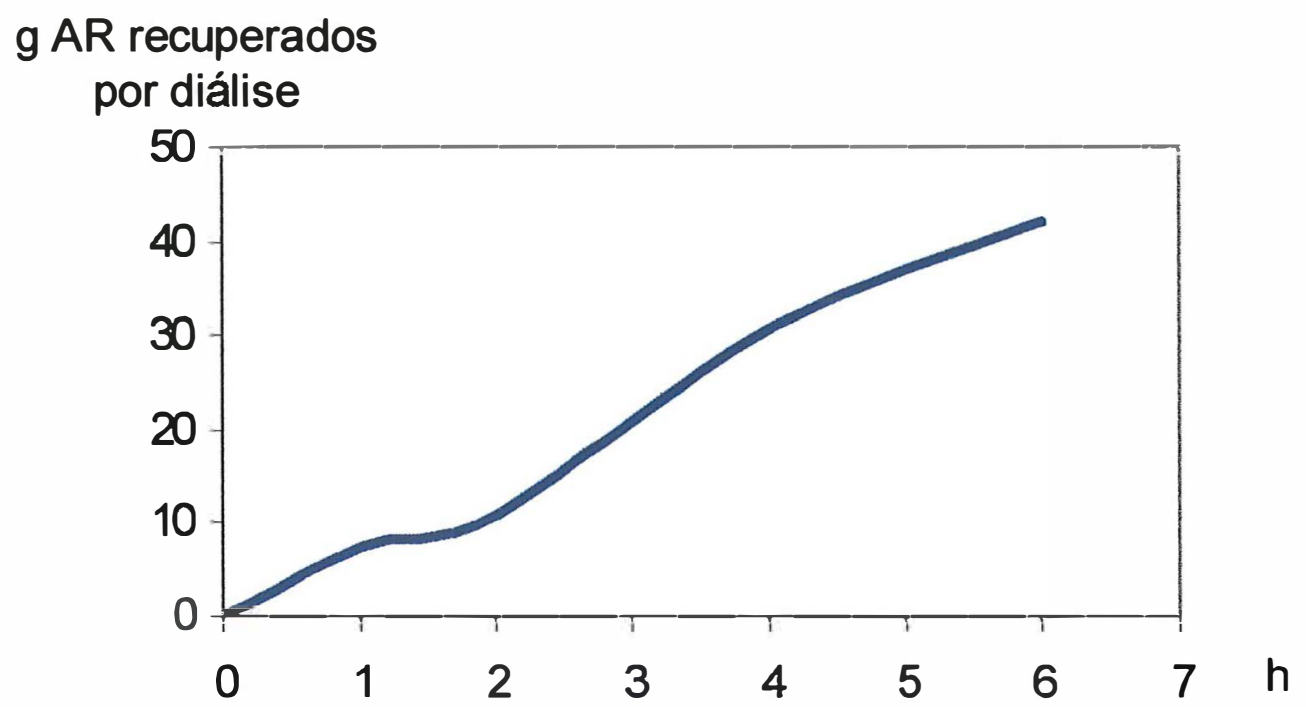

Figura 14. Quantidade de AR recuperado por diálise em função do tempo. 
A eficiência do reator não foi considerada boa do ponto de vista industrial. Em 6 horas de funcionamento, $42 \mathrm{~g}$ de AR foram recuperados, num total de $85 \mathrm{~g}$ (500 $\mathrm{ml}$ com 17\% ART) com 8 metros de membrana de diálise. Entretanto, o principal fator que desestimula o desenvolvimento desse reator é a sua dificuldade de manejo, pois a membrana está sujeita a estourar e o conserto do sistema é muito dificultado.

\subsection{Imobilização em Sílica de Porosidade Controlada (SPC)}

Após a imobilização em SPC, foi feita a avaliação do processo com a análise do sobrenadante. Foram usadas 9,3 U da enzima para a imobilização, sendo que no sobrenadante foi detectado 0,7 U. Portanto, 8,6 U da inulinase foram imobilizadas em $200 \mathrm{mg}$ de SPC. Dessa forma a taxa de imobilização foi de $43 \mathrm{U} / \mathrm{g}$ de SPC.

Como a atividade da inulinase imobilizada em sílica demonstrou ser muito alta e devido às dificuldades em se trabalhar com uma quantidade muito pequena desse material, a avaliação desse suporte foi feita com um tampão de inulina $1 \%$, ao invés de $0,1 \%$.

Após a lavagem da sílica, foi feita a avaliação com $50 \mathrm{ml}$ de tampão $1 \%$ de inulina com $200 \mathrm{mg}$ de peso seco de SPC cataliticamente ativa. Foram realizados 3 ensaios sucessivos com o mesmo suporte para verificar se a atividade se mantinha ou se exauria. Entre um ensaio e outro, foi feita uma lavagem, com tampão sem 
inulina, da sílica e renovado o substrato.

Os resultados são expressos na Figura 15.

$\%$ de hidrólise

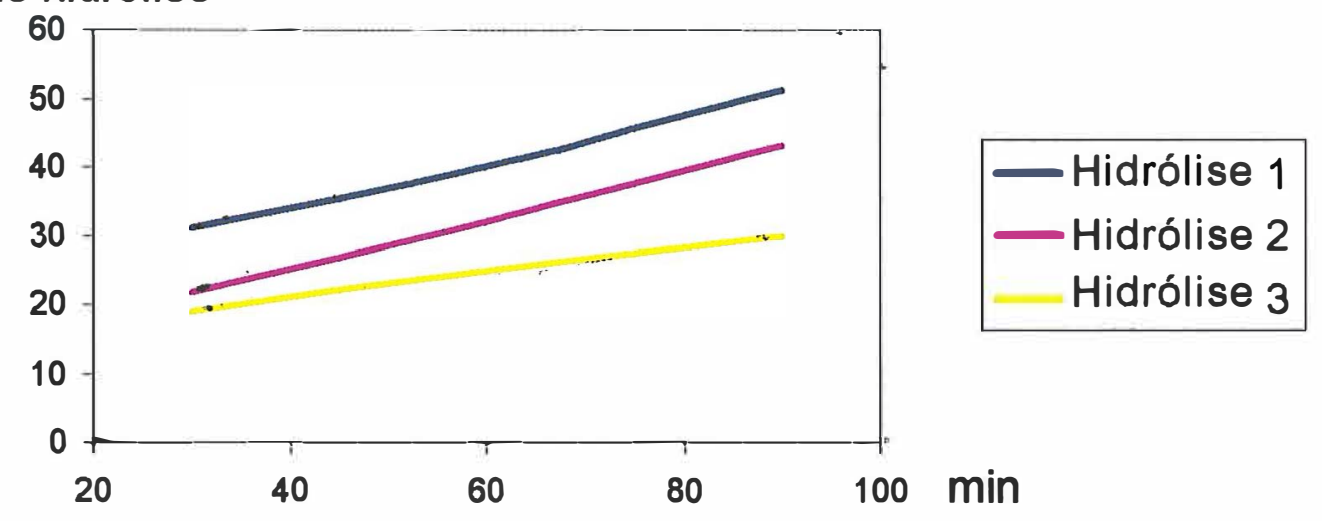

Figura 15. Avaliação da imobilização da inulinase em SPC em três ensaios consecutivos, em substrato $10 \mathrm{~g} / \mathrm{l}$ inulina a temperatura de $45^{\circ} \mathrm{C}$ e $\mathrm{pH} 7,0$, com $200 \mathrm{mg}$ de suporte.

A porcentagem de hidrólise vai decaindo nas bateladas subsequentes devido à redução da atividade da enzima durante o processo. Apesar da enzima não estar se desprendendo do suporte, a atividade enzimática vai diminuindo, indicando inativação da inulinase. O terceiro ciclo de hidrólise teve uma redução média de $37 \%$ em relação ao primeiro ciclo.

Devido ao sucesso da imobilização da inulinase em SPC, os parâmetros determinados para a enzima na forma livre foram reavaliados para a enzima imobilizada.

A SPC com a inulinase imobilizada é um material de difícil pesagem, pois o mesmo não pode ser seco, pois causaria danos irreversíveis à enzima. Além disso, como a atividade enzimática é 
muito alta em uma quantidade muito pequena de suporte, um mínimo erro na pesagem (devido à umidade) provocaria uma discrepância muito grande nos resultados. Entretanto também não seria viável utilizar apenas uma amostra do suporte de imobilização (variando-se apenas a temperatura ou o $\mathrm{pH}$ ) pois, conforme o progresso dos ensaios, sua atividade iria decrescer continuamente, mascarando os resultados.

Dessa forma, para a elaboração da curva de temperatura, foram obtidas duas quantidades iguais de SPC quanto a atividade enzimática (não ao peso), igualando-se a sílica até a análise das duas amostras apresentarem resultados iguais de atividade. Feito isso, uma das amostras foi analisada a partir da menor temperatura avaliada até a mais alta e a outra o inverso, calculando-se a média. Os dados foram obtidos em 3 repetições, sendo que, a cada nova análise foi feita uma lavagem da sillica com tampão citrato-fosfato pH 7,0.

A curva de $\mathrm{pH}$ foi feita do mesmo modo que a de temperatura, sendo que as lavagens eram feitas com o tampão (sem inulina) no $\mathrm{pH}$ a ser avaliado.

Os resultados estão descritos nas Figuras 16 e 17. 
$\mu \mathrm{mol} \mathrm{AR} / \mathrm{ml} / \mathrm{min}$

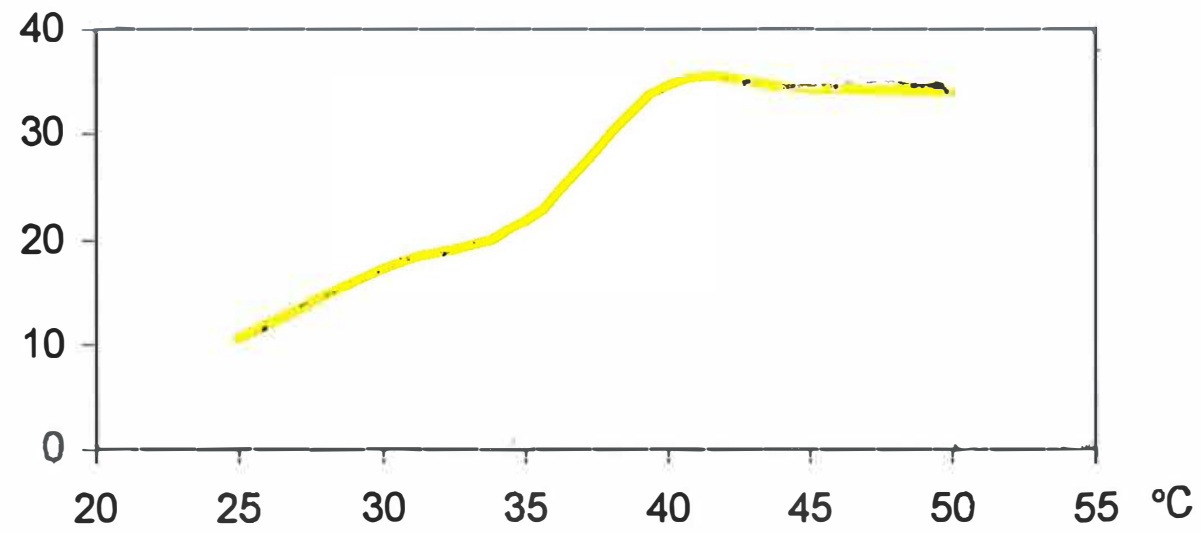

Figura 16. Curva de temperatura da inulinase imobilizada em SPC, em pH 7,0.

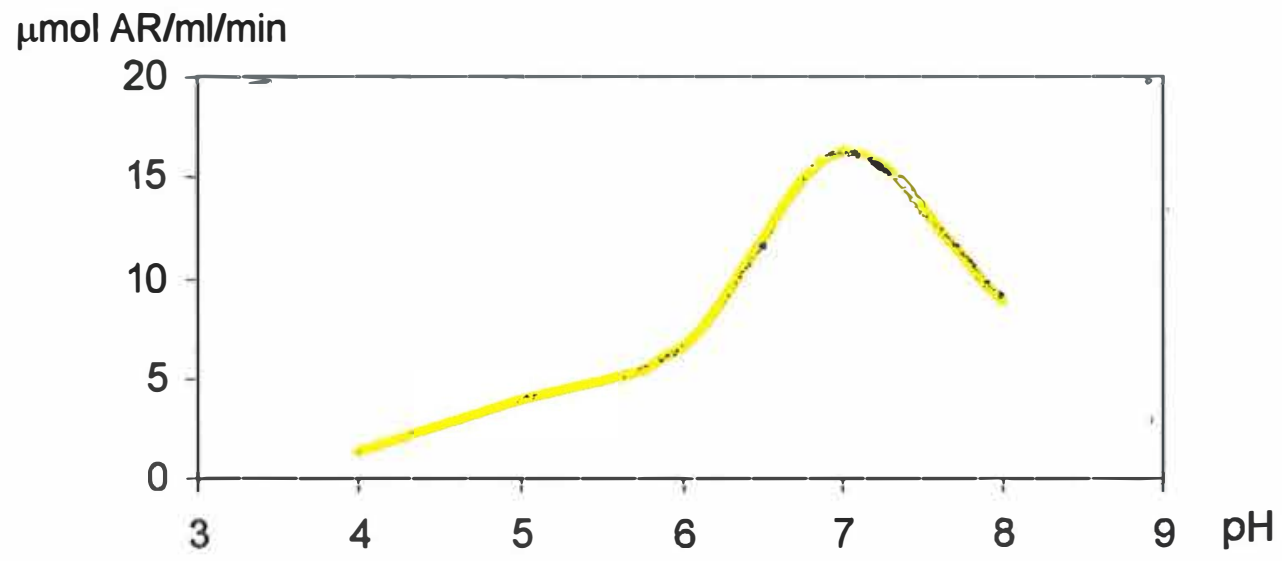

Figura 17. Curva de pH da inulinase imobilizada em SPC, a $45^{\circ} \mathrm{C}$.

Nota-se, dessa forma, que o $\mathrm{pH}$ e a temperatura ótimos não sofreram grandes alterações com o processo de imobilização em SPC. A curva de temperatura para a enzima imobilizada sofreu uma ampliação de sua faixa ótima, o que, do ponto de vista operacional é uma vantagem pois o seu controle não precisa ser tão rígido. 


\section{CONCLUSÕES}

A inulina de $H$. tuberosus pode ser hidrolizada em uma única etapa, produzindo xaropes de frutose de alta concentração, podendo competir com os HFCS e UHFCS.

Todas as etapas do processo foram consideradas viáveis, como a extração da inulina, a produção do extrato enzimático, a imobilização da enzima em SPC e a hidrólise do substrato.

A imobilização em SPC foi a que proporcionou os melhores resultados de hidrólise do substrato, apesar da perda rápida de atividade enzimática, o que requer estudos adicionais visando a retenção da atividade nesse suporte por um tempo maior.

A inulinase imobilizada em SPC proporcionou uma vantagem no sentido operacional de um reator enzimático, visto que a faixa ótima de temperatura da enzima sofreu um alargamento, ou seja, para a enzima livre, a temperatura ótima de reação é de $45^{\circ} \mathrm{C}$ e para a enzima imobilizada em SPC a temperatura ótima vai de $40^{\circ}$ a $50^{\circ} \mathrm{C}$. Portanto o controle da temperatura não precisa ser tão rígido para a enzima imobilizada. 


\section{REFERÊNCIAS BIBLIOGRÁFICAS}

ABDELLAH, H.A.; BAKER, A.T.M.; SHEKIB, L.A.; EL-IRAQI, S.M. Characteristics of invertase immobilized on three different types of supports. Food Chemistry, v.43, n.5 p.369-375, 1992.

ANTRIM, R.L.; COLILLA, W.; SCHNYDER, B.J. Glucose isomerase production of hig-fructose syrups. In: WINGARD, L.B. J.; KATCHALSKI-KATZIR, E; GOLDSTEIN, L. (ed.) Applied biochemistry and bioengineering: enzyme technology. New York: Academic Press, 1979. v.2, cap.4, p.98-156.

BARKER, S.A.; PETCH, G.S. Enzymatic processes for high-frutose corn syrup. In: WOODWARD, J. (ed.) Immobilised cells and enzymes: a practical approach. Washington: IRL Press, 1985. cap.4, p.93-108.

BOCK, 1998 http://www.mpiz-koeln.mpg.de/ rsaedler/schau/ HelianthustuberosusL/Jer_choke.html em 20/08/1998. 
BOURGET, L.; CHANG, T.M. Phenylalanine ammonia-lyase immobilized in semipermeable microcapsules for enzyme replacement in phenylketonuria. FEBS Letters, v.180, n.1, p.5-8, Jan. 1985.

BRODELIUS, P. Industrial applications of immobilized biocatalysts. In: GHOSE T.K.; FIECHTER, A.; BLAKEBROUGH, N. Advances in biochemical engineering: immobilized enzymes I. New York: Springer-Verlag, 1978. vol.10, cap.4, p.75-130.

CHANG, T.M. The in vivo effects of semipermeable microcapsules containing L-asparaginase on 6C3HED lymphosarcoma. Nature, v.8, n.229, p.117-118, Jan 1971.

CHANG, T.M.S. Biomedical applications of artificial cells containing immobilized enzymes, proteins, cells, and other biologically active materials. In: GHOSE, T.K.; FIETCHTER, A.; BLAKEBROUGH, N. (Ed.) Advances in biochemical engineering: immobilized enzymes II. Berlim: Springer-Verlag, 1979. v.12, p.263-282.

CHIBATA, I.; TOSA, T. Industrial applications of immobilized enzymes and immobilized microbial cells. In: WINGARD, L.B. J.; KATCHALSKI-KATZIR, E; GOLDSTEIN, L. Applied biochemistry and bioengineering: enzyme technology. New York: Academic Press, 1976. v.1, cap.5, p.329-358. 
CHIBATA, I.; TOSA, T.; SATO, T. Immobilized biocatalysts to produce amino acids and other organic compounds. In: LASKIN, A.J. (Ed.) Enzymes and immobilized cells in biotechnology. California: The Benjamin/Cummings Publishing, 1985. p.37-70.

CONG, L; KAUL, R; DISSING, U; MATTIASSON, B A model study on Eudragit and polyethyleneimine as soluble carriers of alpha-amylase for repeated hydrolysis of starch. Journal of Biotechnology, v.42, n.1, p.75-84, 1995

FLEMING, S.; GOOTWASSINK, J.W.D. Preparation of high-fructose syrup from the tuber of the jerusalem artichoke (Helianthus tuberosus L.) - CRC - Critical Review Food Science and Nutrition, v.12, n.1, p.1-28, 1979.

FLORÊNCIO, J.A. Imobilização de inulinase I fúngica e inulinase || bacteriana utilizando vários suportes. Curitiba, 1995. 79p. Tese (Mestrado) - Universidade Federal do Paraná.

GASPARI, J.W. Seleção e melhoramento de linhagens de Kluyveromyces marxianus quanto à atividade inulinolítica. Piracicaba, 1995. 36p. Monografia (Graduação) - Escola Superior de Agricultura "Luiz de Queiroz", Universidade de São Paulo. 
GEITEL, B.; RYL, W.; FIEDLER, B Microbial hydrolysis of inulincontaining juice from Jerusalem artichoke to fructose-syrup. Zentralblatt fur Mikrobiologie. v.148, n.3, p.205-211, 1993.

GEMEINER, P.; REXOVÁ-BENKOVÁ, L; SVEC, F.; NORRLÖW, O. Natural and synthetic carriers suitable for immobilization of viable cells, active organelles, and molecules. In: VELIKY, I.A.; MCLEAN, R.J.C. Immobilized biosystems: theory and practical applications. New York, Blackie Academis \& Professional, 1994. p.1-128.

GOLDSTEIN, L.; MANECKE, G. The chemistry of enzyme immobilization. In: WINGARD, L.B. J.; KATCHALSKI-KATZIR, E; GOLDSTEIN, L. Applied biochemistry and bioengineering: Enzyme technology. New York: Academic Press, 1976. v.1, cap.2, p.23-127.

GUPTA, A.K.; RATHORE, P.; KAUR, N.; SINGH, R. Production, thermal stability and immobilisation of inulinase from Fusarium oxysporum. Journal of chemical technology and biotechnology. v. 47, n.3, p.245-257, 1990.

HAYASHI, S.; MATSUZAKI, K.; INOMATA, Y.; TAKASAKI, Y.; IMADA, K. Properties of Aspergillus japonicus beta-fructofuranosidase immobilized on porous silica. World Journal of Microbiology \& Biotechnology, v.9, n.2, p.216-220, 1993. 
HERBERT, D.; PHIPPS, P.J.; STRANGE, R.E. Chemical analysis of microbial cells. In: NORRIS, J.R.; RIBBONS, D.W. (ed.) Methos in microbiology Vol 5B, London: Academic Press, 1971, 695p, cap.3, p.209-344.

HIGLEY, N.A.; WHITE, J.S. Trends in fructose availability and consumption in the United States. Food and Technology. Chicago, v.45, n.10, p.118-122, 1991.

JOSHI, S.S.; KUSUMAKUMARI, P.; SEENAPPA, K.; RADHAMANI, A. Biochemical studies in some varieties of Jerusalem artichoke (Helianthus tuberosus L.). Crop Research, v.8, n.1, p.92-99, 1994.

KENT , C.; ROSEVEAR, A.; THOMSON, A.R. Enzymes immobilized in inorganic supports. In: WISEMAN, A. (Ed.) Topics in enzyme and ferment biotechnology 2. New York: John Wiley \& Sons, 1978. cap.2, p.12-119.

KIERSTAN, M. Production of fructose syrups from inulin. Process Biochemistry, p.2-3, May/1980. 
KIERSTAN, M.P.J.; COUGHLAN, M.P. Immobilisation of cells and enzymes by gel entrapment. In: WOODWARD, J. (Ed.) Immobilised cells and enzymes: a practical approach. Washington: IRL Press, 1985. cap.2. p.39-54.

KIM, D.M.; KIM, H.S. Continuous production of gluconic acid and sorbitol from Jerusalem artichoke and glucose using an oxidoreductase of Zymomonas mobilis and inulinase. Biotechnology and Bioengineering, v.39, n.3, p.336-342, 1992.

KIM, W.Y.; BYUN, S.M.; UHM, T.B. Hydrolysis of inulin from Jerusalem artichoke by inulinase immobilized on aminoethylcellulose. Enzyme and Microbial Technology, v.4, n.4 p.239-244, 1992.

KIM, C.H.; RHEE, S.K. Fructose production from Jerusalem artichoke by inulinase immobilized on chitin. Biotechnology Letters, v.11, n.3, p.201-206, 1989.

KLEESSEN, B.; SYKURA, B.; ZUNFT, H.J.; BLAUT, M. Effects of inulin and lactose on fecal microflora, microbial activity, and bowel habit in elderly constipated persons. American Journal of Clinical Nutrition, v.65, n.5, p.1397-1402, May. 1997. 
LAGUNA, S.E. Genética e melhoramento de leveduras para a bioconversão de extratos de Helianthus tuberosus L. Piracicaba, 1986. 173p. Tese (Doutorado) - Escola Superior de Agricultura "Luiz de Queiroz", Universidade de São Paulo.

LAGUNA, S.E.; TAVARES, F.C.A. Atividade da inulinase em leveduras e fermentações de extratos de Helianthus tuberosus L. Revista de Microbiologia, v.16, n.2, p.127-131, 1985.

LALYMENKO, L.A.; LALYMENKO, N.K. Growing Jerusalem artichoke [Helianthus tuberosus] and turnsole hybrid [H. tuberosus $X \mathrm{H}$. annuus] on sandy soils irrigated with urban sewage. Problems of Desert Development. 1995, No. 3, 90-95. Ref. 27 em FSTA on CD-ROM, 1969-1995/

LEE, P.M.; LEE, K.H.; SIAW, Y.S. Covalent immobilization of aminoacylase to alginate for L-phenylalanine production. Journal of Chemical Technology and Biotechnology, v.58 n.1, p.65-70, 1993.

LODDER, J. The yeast: a taxonomic study. Amsterdan, North Holland, 1970. 1385p. 
MARTINEK, K.; GOLDMACHER, V.S.; KLIBANOV, A.M.; BEREZIN, I.V. Denaturing agents (urea, acrylamide) protect enzymes against irreversible thermoinactivation: a study with native and immobilized alpha-chymotrypsin and trypsin. FEBS Letters, v.1;51(1):1521551975 Mar

MILCENT, P.F. Contribuição ao estudo da hidrólise contínua da sacarose por catálise heterogênea em leito de resina trocadora de íons. Curitiba, 1989. 262p. Tese (Mestrado). Universidade Federal do Paraná.

MULLIN, W.J.; MODLER, H.W.; FARNWORTH, E.R.; PAYNE, A. The macronutrient content of fractions from Jerusalem artichoke tubers (Helianthus tuberosus). Food Chemistry; v.51, n.3, p.263-269, 1994.

NAKAMURA, T.; FUGITA, T.; OHTA, K. Properties and immobilization of extracellular endoinulinase (P-III) from Aspergillus niger. Bulletin of the Faculty of Agriculture, v.43, n.2, p.103-109, 1997.

NAKAMURA, T.; OGATA, Y.; SHITARA, A.; NAKAMURA, A.; OHTA, K. Continuous production of fructose syrups from inulin by immobilized inulinase from Aspergillus niger mutant 817 . Journal of Fermentation and Bioengineering, v.80, n.2, p.164-169, 1995. 
NIGHOJKAR, A.; SRIVASTAVA, S.; KUMAR, A. Production of low methoxyl pectin using immobilized pectinesterase bioreactors. Journal of Fermentation and Bioengineering; v.80, n.4, p.346-349, 1995.

PEREIRA, G.A.G. Atividade inulinolítica extracelular em Kluyveromyces marxianus. Piracicaba, 1989. 152p. Tese (Mestrado) - Escola Superior de Agricultura "Luiz de Queiroz", Universidade de São Paulo.

PLAHUTA-P; RASPOR-P Cellulase immobilization on Ca-alginate beads. Food Technology and Biotechnology; v.34, n.2/3, p.77-80, 1996.

PURI,M; MARWAHA,S.S.; KOTHARI, R.M. Studies on the applicability of alginate-entrapped naringinase for the debittering of kinnow juice. Enzyme and Microbial Technology; v.18, n.4, p.281-285, 1996.

SIU CHONG E.D.; CHANG T.M. In vivo effects of intraperitoneally injected L-asparaginase solution and L-asparaginase immobilized within semipermeable nylon microcapsules with emphasis on blood L-asparaginase, 'body' L-asparaginase, and plasma L-asparagine levels. Enzyme. v.18, n.3, p.218-239, 1974. 
SHALLENBERGER, R.S. Advanced sugar chemistry: principles of sugar stereochemistry. Connecticut: AVI Publishing Company, 1982. 323p.

SOBOTKA, L.; BRATOVA, M.; SLEMROVA, M.; MANAK, J.; VIZD'A, J.; ZADAK, $Z$. Inulin as the soluble fiber in liquid enteral nutrition. Nutrition. v.13, n.1, p.21-25, 1997.

SOLOMON, B. Starch hydrolysis by immobilizes enzymes industrial applications. In: GHOSE, T.K.; FIETCHTER, A.; BLAKEBROUGH, N. (Ed.) Advances in biochemical engineering: Immobilized enzymes I. Berlim: Springer-Verlag, 1978. vol.10, p.131-177.

SOUZA, L.C.; MILCENT, P.F.; CORREA, J.B.C. Frutose a partir de sacarose e glicose: uma revisão bibliográfica. Boletim CEPPA, v.8, n.1, p.47-73, jan./jun. 1990.

SRIVASTAVA, S.; NIGHOJKAR, A.; KUMAR, A. Demethoxylation of pectin using immobilized Cuscuta reflexa pectin methylesterase. Genetic Engineer \& Biotechnologist, v.16, n.2, p.73-80, 1996. 
SWEIGART, D. Industrial applications of immobilized enzymes: a commercial overview. In: WINGARD, L.B. J.; KATCHALSKI-KATZIR, E; GOLDSTEIN, L. Applied biochemistry and bioengineering: enzyme technology. New York: Academic Press, 1979. vol.2, cap.7, p.209-218.

SYNOWIECKI, J.; SIKORSKA-SIONDALSKA, A.; EL-BEDAWEY, A.E. Adsorption of enzymes on krill chitin modified with carbon disulfide. Biotechnology and Bioengineering, v.29, p.352-354, 1987.

TEAGUE, J.R.; ARNOLD, E.C. UOP technology for the production of fructose sweetners. Sugar y Azucar, v.78, n.8, p.18-19, 1983.

TOSA, T.; MORI, T.; CHIBATA, I. Studies on continuous enzyme reactions part VI. Enzymatic properties of the DEAE-Sephadexaminoacylase complex. Agricultural and Biological Chemical, v.33, p.1053-1059, 1969.

TREVAN, M.D. Immobilized enzymes: an introduction and applications in biotechnology. New York: John Wiley \& Sons, 1980. 138p. 
YUN, J.W.; KIM, D.H.; KIM, B.W.; SONG, S.K. Production of inulooligosaccharides from inulin by immobilized endoinulinase from Pseudomonas sp. Journal of Fermentation and Bioengineering, v.84, n.4, p.369-371, 1997.

WANDREY, C.; FLASCHEL, E. Process development and economic aspects in enzyme engineering: acylase L-methionine system. In: GHOSE, T.K.; FIETCHTER, A.; BLAKEBROUGH, N. (Ed.) Advances in biochemical engineering: Immobilized enzymes II. Berlim: Springer-Verlag. 1979. vol.12, p.147-218.

ZABORSKY, O.R. Immobilized enzymes. Cleveland: CRC Press, 1973.

ZANIN, G.M.; MORAES, F.F. Stability of immobilized amyloglucosidase in the process of cassava starch saccharification. Applied Biochemistry and Biotechnology, v.51/52, p.253262, 1995. 


\section{APENNDICE}


Tabela 1. Atividade inulinolítica em função da temperatura, em um substrato $0,1 \%$ inulina em $\mathrm{pH} 7,0$, realizados em 3 repetições, para a enzima em sua forma livre.

\begin{tabular}{cc}
\hline $\begin{array}{c}\text { Temperatura } \\
{ }^{\circ} \mathrm{C}\end{array}$ & $\begin{array}{c}\text { Atividade } \\
\mu \mathrm{mol} / \mathrm{AR} / \mathrm{ml} / \mathrm{min}\end{array}$ \\
\hline 25 & 3,333 \\
30 & 7,619 \\
35 & 8,571 \\
40 & 9,048 \\
45 & 11,905 \\
50 & 9,524 \\
\hline
\end{tabular}

Tabela 2. Atividade inulinolítica em função do $\mathrm{pH}$, em um substrato $0,1 \%$ inulina a $45^{\circ} \mathrm{C}$, realizados em 3 repetições, para a enzima em sua forma livre.

\begin{tabular}{lc}
\hline $\mathrm{pH}$ & $\begin{array}{c}\text { Atividade } \\
\mathrm{mmol} / \mathrm{AR} / \mathrm{ml} / \mathrm{min}\end{array}$ \\
\hline 3 & 2,551 \\
3,5 & 4,337 \\
4 & 6,037 \\
4,5 & 8,928 \\
5 & 9,438 \\
5,5 & 12,243 \\
6 & 21,171 \\
6,5 & 29,844 \\
7 & 34,945 \\
7,5 & 21,809 \\
8 & 14,284 \\
\hline
\end{tabular}


Tabela 3. Tempo de incubação da inulinase imobilizada em alginato de sódio, nas concentrações de 2 e $4 \%$, pela formação de AR resultante da hidrólise enzimática da inulina.

\begin{tabular}{ccc}
\hline $\begin{array}{c}\text { Tempo } \\
(\mathrm{min})\end{array}$ & $\begin{array}{c}2 \% \\
\mu \mathrm{g} / \mathrm{l} \text { AR }\end{array}$ & $\begin{array}{c}4 \% \\
\mu \mathrm{g} / \mathrm{l} \mathrm{AR}\end{array}$ \\
\hline 1 & 0 & 9 \\
2 & 1 & 14 \\
3 & 5 & 16 \\
4 & 5 & 16 \\
5 & 7 & 18 \\
10 & 14 & 48 \\
15 & 24 & 60 \\
20 & 32 & 106 \\
30 & 54 & 138 \\
45 & 78 & 189 \\
60 & 118 & 262 \\
\hline
\end{tabular}


Tabela 4. Avaliação da perda de atividade da inulinase imobilizada em SPC através de três ensaios consecutivos, com o mesmo suporte, em um substrato $1 \%$ de inulina a $45^{\circ} \mathrm{C}$.

\begin{tabular}{cccc}
\hline $\begin{array}{c}\text { Tempo } \\
(\mathrm{min})\end{array}$ & $\begin{array}{c}\text { hidrólise 1 } \\
(\%)\end{array}$ & $\begin{array}{c}\text { hidrólise 2 } \\
(\%)\end{array}$ & $\begin{array}{c}\text { hidrólise 3 } \\
(\%)\end{array}$ \\
\hline 30 & 31 & 22 & 19 \\
60 & 40 & 32 & 25 \\
90 & 51 & 43 & 30 \\
\hline
\end{tabular}


Tabela 7. Atividade da inulinase imobilizada em SPC em função da temperatura, em um substrato $1 \%$ inulina em $\mathrm{pH} 7,0$.

\begin{tabular}{cc}
\hline $\begin{array}{c}\text { Temperatura } \\
{ }^{\circ} \mathrm{C}\end{array}$ & $\begin{array}{c}\text { Atividade } \\
\mu \mathrm{mol} / \mathrm{AR} / \mathrm{ml} / \mathrm{min}\end{array}$ \\
\hline 25 & $10,5 \mathrm{a}$ \\
30 & $17,0 \mathrm{~b}$ \\
35 & $21,6 \mathrm{c}$ \\
40 & $34,6 \mathrm{~d}$ \\
45 & $34,4 \mathrm{~d}$ \\
50 & $34,1 \mathrm{~d}$ \\
\hline
\end{tabular}

* Letras diferentes indicam valores diferentes segundo teste $\mathrm{F}$ ao nivel de $5 \%$.

Tabela 8. Atividade da inulinase imobilizada em SPC em função do $\mathrm{pH}$, em um substrato $1 \%$ inulina a $45^{\circ} \mathrm{C}$.

\begin{tabular}{cc}
\hline $\mathrm{pH}$ & $\begin{array}{c}\text { Atividade } \\
\mu \mathrm{mol} / \mathrm{AR} / \mathrm{ml} / \mathrm{min}\end{array}$ \\
\hline 4 & $13 \mathrm{a}$ \\
5 & $39 \mathrm{~b}$ \\
6 & $66 \mathrm{c}$ \\
7 & $162 \mathrm{~d}$ \\
8 & $88 \mathrm{e}$ \\
\hline
\end{tabular}

* Letras diferentes indicam valores diferentes segundo teste $\mathrm{F}$ ao nível de $5 \%$. 